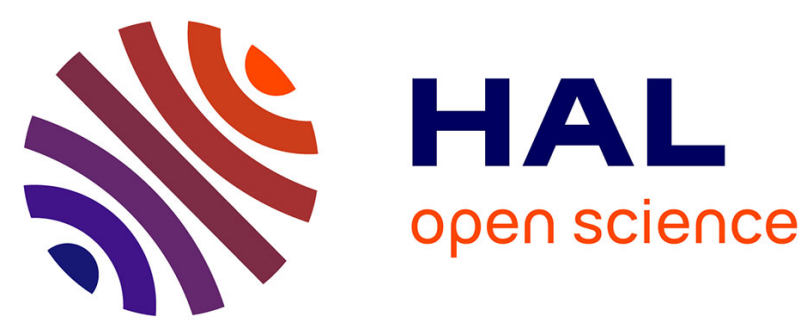

\title{
Mitochondria and endoplasmic reticulum: Targets for a better insulin sensitivity in skeletal muscle?
}

\author{
Alexis Boulinguiez, Bart Staels, Helene Duez, Steve Lancel
}

\section{To cite this version:}

Alexis Boulinguiez, Bart Staels, Helene Duez, Steve Lancel. Mitochondria and endoplasmic reticulum: Targets for a better insulin sensitivity in skeletal muscle?. Biochimica et Biophysica Acta Molecular and Cell Biology of Lipids, 2017, 1862 (9), pp.901 - 916. 10.1016/j.bbalip.2017.05.011 . inserm01575529

\section{HAL Id: inserm-01575529 https://www.hal.inserm.fr/inserm-01575529}

Submitted on 21 Aug 2017

HAL is a multi-disciplinary open access archive for the deposit and dissemination of scientific research documents, whether they are published or not. The documents may come from teaching and research institutions in France or abroad, or from public or private research centers.
L'archive ouverte pluridisciplinaire HAL, est destinée au dépôt et à la diffusion de documents scientifiques de niveau recherche, publiés ou non, émanant des établissements d'enseignement et de recherche français ou étrangers, des laboratoires publics ou privés. 
Mitochondria and endoplasmic reticulum: targets for a better insulin sensitivity in skeletal muscle?

Alexis BOULINGUIEZ ${ }^{a}$, alexis.boulinguiez-2@etu.univ-lille2.fr

Bart STAELS ${ }^{a}$, bart.staels@pasteur-lille.fr

Helene DUEZ ${ }^{\text {a }}$, helene.duez@pasteur-lille.fr

Steve LANCEL ${ }^{\text {a }}$, steve.lancel@univ-lille2.fr

a Univ. Lille, Inserm, CHU Lille, Institut Pasteur de Lille, U1011- EGID,

F-59000 Lille, France

Corresponding author: Steve LANCEL, steve.lancel@univ-lille2.fr

Inserm UMR1011 \& Université de Lille

Institut Pasteur de Lille

1 rue du professeur Calmette

BP245

59019 LILLE - France

\section{Highlights}

- Obesity results in massive lipid overload in non-fat storage tissues

- Lipotoxicity leads to insulin resistance in skeletal muscle, a key metabolic organ

- Mitochondria and endoplasmic reticulum are implicated in muscle insulin resistance

- Targeting both organelles or their connections should be considered in the future 


\section{Abstract (100-250 words)}

Obesity and its associated metabolic disorders represent a major health burden, with economic and social consequences. Although adapted lifestyle and bariatric surgery are effective in reducing body weight, obesity prevalence is still rising. Obese individuals often become insulin-resistant. Obesity impacts on insulin responsive organs, such as the liver, adipose tissue and skeletal muscle, and increases the risk of cardiovascular diseases, type 2 diabetes and cancer. In this review, we discuss the effects of obesity and insulin resistance on skeletal muscle, an important organ for the control of postprandial glucose. The roles of mitochondria and the endoplasmic reticulum in insulin signaling are highlighted and potential innovative research and treatment perspectives are proposed.

Keywords: mitochondria, endoplasmic reticulum, insulin resistance, skeletal muscle, lipid

\section{Introduction}

Modern lifestyle is characterized by high caloric diets and a sedentary behaviour, promoting an imbalance between energy uptake and expenditure, and causing body weight gain. In the last decades, obesity has become epidemic. According to the World Health Organization, more than 1.9 billion adults are obese, i.e. with a body mass index exceeding 30 . In less than 35 years, the prevalence of obesity has more than doubled, although this is theoretically preventable by appropriate lifestyle measures and bariatric surgery, which is the most effective approach in inducing weight loss. The consequences of this epidemic are dramatic, as obesity increases 
the risk of cardiovascular diseases, musculoskeletal disorders, cancer and metabolic diseases. In particular, increased blood levels of free fatty acids (FFA) and glucose observed in obesity trigger insulin resistance that will ultimately lead to type 2 diabetes [1].

Skeletal muscle is one of the most important organs in the control of glucose homeostasis. Indeed, skeletal muscle accounts for $30 \%$ of total body weight and it is estimated that nearly $80 \%$ of glucose during euglycemic hyperinsulinemic clamps is taken up by skeletal muscle [2]. Therefore, it is of importance to further understand the underlying mechanisms responsible for the development of obesity-induced insulin resistance in skeletal muscle in order to develop new therapeutic strategies restoring glucose homeostasis.

Insulin resistance is defined as a lower response of its target organs, such as the liver, white adipose tissue and skeletal muscle, to insulin action. In physiological states, insulin produced by pancreatic $\beta$-cells in response to postprandial hyperglycemia is secreted in blood and binds in target tissues to the Insulin Receptor (IR). Conformational changes of the receptor lead to autophosphorylation of its intracellular subunits on tyrosine amino acids (Figure 1). Consequently, Insulin Receptor Substrates (IRS) are phosphorylated on tyrosine residues, allowing IRS to interact with Phosphatidyllnositol-3-Kinase (PI3K) through its Src Homology 2 (SH2) binding domain. PI3K converts Phosphatidyllnositol biPhosphate (PIP2) into Phosphatidyllnositol triPhosphate (PIP3). PIP3 formation allows the recruitment of the Protein Kinase B (PKB), also known as Akt, to the plasma membrane. To be fully activated, Akt is subsequently phosphorylated on serine 473 by the rictor-mammalian 
Target Of Rapamycin (mTOR) [3], which then facilitates threonine 308 phosphorylation by the Phosphoinositide-Dependent Kinase 1 (PDK1) [4].

After its translocation back into the cytoplasm, Akt phosphorylates several substrates, mobilizing GLUcose Transporters 4 (GLUT4) to the plasma membrane, thereby enhancing glucose uptake capacity. Akt also increases glycolysis and glycogen production through phosphorylation and inhibition of Glycogen Synthase Kinase $3 \beta$ (GSK3 $\beta$ ), which in turn promotes Glycogen Synthase (GS) activity [1].

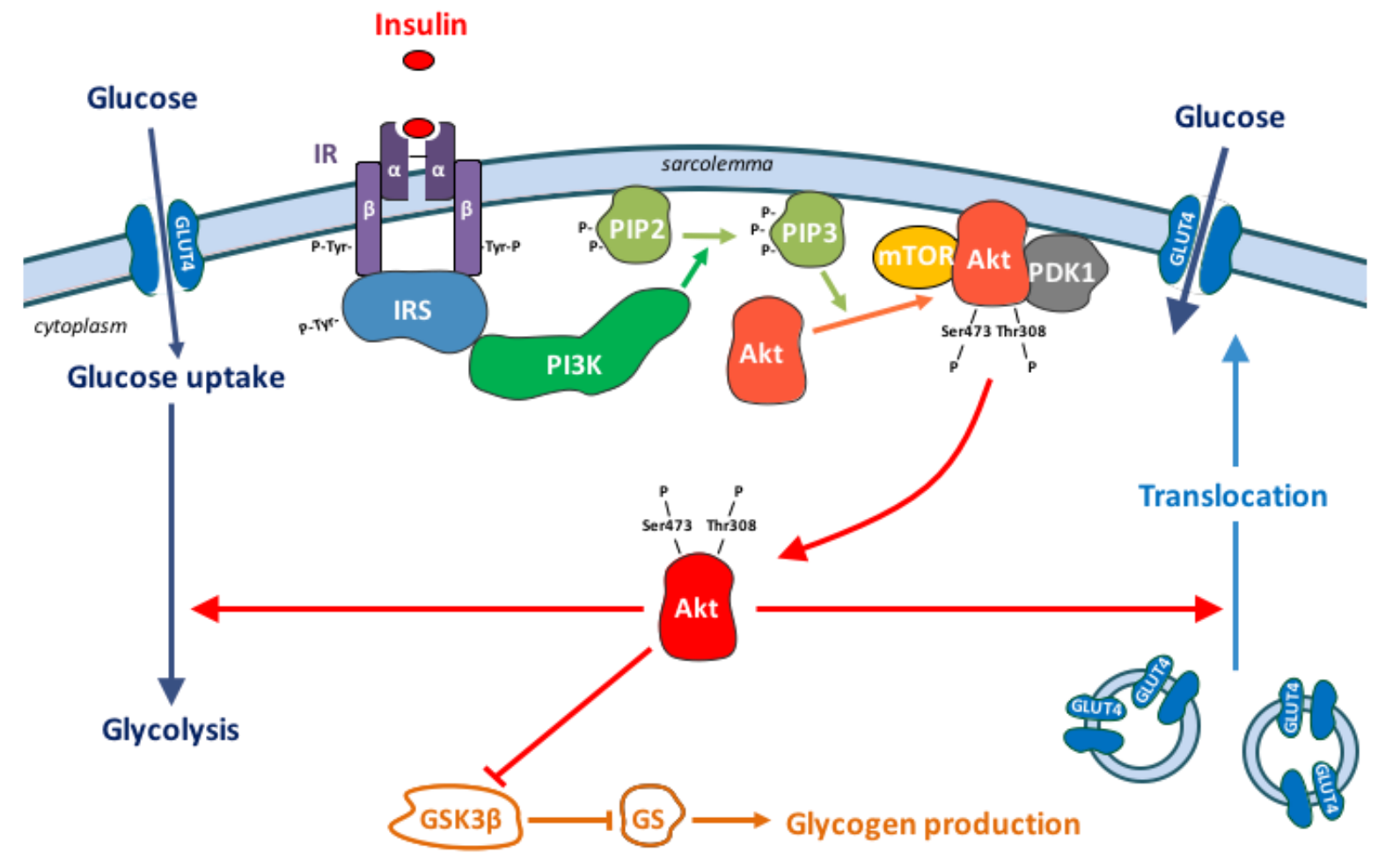

Figure 1: Schematic representation depicting insulin signaling in skeletal muscle. Insulin binds to its receptor and activates Akt. In turn, Akt promotes glycolysis, increases GLUcose Transporter 4 (GLUT4) translocation to the plasma membrane and, by phosphorylating and inhibiting Glycogen Synthase Kinase $3 \beta$ (GSK3 $\beta$ ), activates glycogen production by Glycogen Synthase (GS). Insulin Receptor (IR), 
Insulin Receptor Substrate (IRS), mammalian Target Of Rapamycin (mTOR), Phosphatidyllnositol-3-Kinase (PI3K), Phosphatidyllnositol biPhosphate (PIP2), Phosphatidyllnositol triPhosphate (PIP3), Phosphoinositide-Dependent Kinase 1 (PDK1).

Obesity is associated with skeletal muscle lipid overload. This is due to an increased synthesis and export of Very-Low-Density Lipoproteins (VLDL) by the liver [5], increasing the delivery of FFA to peripheral organs. Ectopic fat deposition [6], i.e. TriGlycerides (TG) accumulation in non fat-storage tissues, notably skeletal muscle, occurring when white adipose tissue reaches its physical and functional limits [7], promotes insulin resistance and type 2 diabetes. At the cellular level, lipid-induced skeletal muscle insulin resistance has been associated with ceramide accumulation, DiAcylGlycerol (DAG) generation and Protein Kinase C (PKC) activation. These events lead to the impairment of IR-IRS-PI3K-Akt signaling and to a reduction in glucose uptake (For review: [1]).

In this context, a debated topic is whether mitochondria and Endoplasmic Reticulum (ER) participate to lipid-induced skeletal muscle insulin resistance [8]. Here we summarize the most recent knowledge regarding both organelles. We also give an overview of the treatments used in humans to improve insulin sensitivity in skeletal muscle through, at least in part, changes in mitochondria and ER functions. Finally, we propose several research axes to improve skeletal muscle insulin sensitivity.

To help both specialist and non-specialist readers, we provide a table referencing all proteins mentionned in the text with their localization and function (Table 1). 


\section{Mitochondria and skeletal muscle insulin resistance}

Mitochondria are double-membrane organelles dedicated to energy production through OXidative PHOSphorylation (OXPHOS). Four respiratory complexes transporting electrons from reduced coenzymes, e.g. $\mathrm{NADH}, \mathrm{H}^{+}$and $\mathrm{FADH}$, provided by the Krebs/TriCarboxylic Acid (TCA) cycle fed by glycolysis-produced pyruvate and lipid $\beta$-oxidation, generate a proton gradient across the mitochondrial inner membrane. The resulting electrochemical gradient provides the energy required to convert Adenosine DiPhosphate (ADP) into Adenosine TriPhosphate (ATP) by ATP synthase. Therefore, logically, initial efforts focused on how alterations in metabolic pathways could alter glucose or lipid metabolism, leading to mitochondrial dysfunction and impairment of ATP production. However, more recently, research interests have shifted to the pathways regulating mitochondrial population quality, including de novo formation of mitochondria (biogenesis), exchange of components between mitochondria (dynamics) and removal of damaged mitochondria (mitophagy). Below, we briefly discuss the main pathways that alter the primary function of mitochondria as well as mitochondria population quality.

\subsection{Primary mitochondrial alterations in insulin resistance}

Although the results slightly differ between studies, probably due to the type and duration of the diets as well as the muscle type examined, most studies report alterations in skeletal muscle TCA cycle [9], loss of respiratory mitochondrial complex I and IV activity [10], lowered mitochondrial respiration and ATP production [11,12] in High-Fat Diet (HFD)-fed rodents. 
As lipids have deleterious effects on insulin sensitivity, the consequences of a substrate switch from FFA to glucose have been tested by inhibiting Carnitine PalmitoylTransferase 1 (CPT1), the rate-limiting enzyme controlling long-chain acylcoenzyme A entry into mitochondria. Short-term (8 days) CPT1 inhibition with etomoxir in humans [13] or partial deletion of CPT1 in mice [14] improves skeletal muscle insulin sensitivity as revealed by enhanced insulin-dependent Akt phosphorylation, GLUT4 translocation to the sarcolemmal membrane [13] and increased glucose oxidation capacity [14]. However, chronic CPT1 inhibition for four weeks by etomoxir added in food [15] or the long term effects of CPT1 deletion [16] in rodents are deleterious as Glucose Disposal Rate (GDR) [15] and skeletal muscle insulin signaling [16] are reduced upon insulin stimulation. Under these conditions, a tight correlation is found between intramyocellular lipid concentration and the GDR $[15,16]$.

Mitochondrial fatty acid oxidation generates higher amounts of Reactive Oxygen Species (ROS) compared to carbohydrate oxidation. Consistently, excessive fat intake results in enhanced ROS generation by skeletal muscle mitochondria both in animals and humans [17-20]. Despite this correlation, the causative link between mitochondrial ROS production and insulin resistance in skeletal muscle remains unclear as mitochondria-targeted catalase Manganese SuperOxide Dismutase (MnSOD) [18] overexpression prevents HFD-induced insulin resistance, while antioxidant pharmacological treatments do not despite efficient ROS sequestering $[20,21]$.

\subsection{Mitochondrial population quality control pathways}




\section{a. Mitochondrial biogenesis}

Peroxisome Proliferator-Activated Receptor (PPAR) y Coactivator-1 a (PGC-1 $\alpha$ ) promotes mitochondrial biogenesis. However, conflicting results have been reported in rodents upon chronic (between 3 and 25 weeks) HFD feeding: on the one hand, increased expression of PGC-1 $\alpha$ and citrate synthase, a marker of mitochondrial mass, is observed [22,23], while on the other hand reduced PGC-1a mRNA expression is found associated with decreased OXPHOS capacity and incomplete fatty acid oxidation $[19,24,25]$. The source of fat, animal species and assessed muscle could explain these discrepancies. Nevertheless, decreased PGC-1a gene expression is also found in muscle biopsies from insulin-resistant prediabetic $[26,27]$ and type 2 diabetic patients [27-29]. Moreover, activation or overexpression of the deacetylase SIRTuin 1 (SIRT1), which targets and activates PGC-1a, exerts beneficial effects on mitochondrial mass and skeletal muscle insulin resistance $[30,31]$. Consistently, PGC-1a overexpression improves insulin sensitivity in rat tibialis anterior [32] and reverses skeletal muscle insulin-resistance in obese rats [33].

\section{b. Mitochondrial dynamics}

Mitochondria are highly dynamic organelles moving along the cytoskeleton, which can fuse or divide to adapt their metabolism according to the environment [34]. Several proteins with GTPase activity control mitochondrial remodelling. Mitofusins (Mfn1 and Mfn2) and Optic atrophy 1 (Opa1) are the major proteins involved in the fusion of outer and inner mitochondrial membranes, respectively. Dynamin-related protein 1 (Drp1) and its receptor protein Fission 1 (Fis1) are involved in mitochondrial 
fission [34]. Changes in the machineries involved in mitochondrial dynamics have been detected in skeletal muscle from HFD-fed mice [35].

On the fusion side, insulin-resistant skeletal muscle from obese Zucker rats expresses less Mfn2 [36]. Accordingly, Mfn2-deficient mice or muscle-specific Mfn2 silencing by miRNA electroporation in tibialis anterior and gastrocnemius muscles reduces the mitochondrial respiratory control ratio, increases oxidative stress (higher $\mathrm{H}_{2} \mathrm{O}_{2}$ production) and triggers defective insulin signaling, e.g. reduced Akt phosphorylation and lower interaction between IRS1 and the p85 subunit of PI3K upon insulin stimulation [37]. Skeletal muscle Mfn2 overexpression by adenovirus infection in HFD-fed rats also reduces lipid intermediates, e.g. DAG and ceramides, increases GLUT4 expression and translocation, and insulin sensitivity $[38,39]$. Interestingly, overexpression of miR-106b, whose expression is increased in diabetic patients and HFD-induced insulin resistant mice [40,41] and which inhibits Mfn2 translation by targeting the $3^{\prime}$ untranslated region of Mfn2 mRNA [42], is accompanied by reduced glucose uptake and impaired insulin signaling [42]. Consistently, Mfn2 expression levels are reduced in skeletal muscle from obese men and women $[36,43]$.

On the fission side, palmitate treatment in differentiated $\mathrm{C} 2 \mathrm{C} 12$ muscle cells induces mitochondrial fragmentation through Drp1, an effect prevented by the transfection of a dominant negative-Drp1 form and Drp1-specific shRNA-mediated knock-down [44]. Interestingly, treatment of $o b / o b$ mice with the cell-permeable selective inhibitor of Drp1 Mdivi-1 restores the mitochondrial network and is associated with improved insulin sensitivity [44]. Overall, mitochondrial fission inhibition as well as mitochondrial fusion increase skeletal muscle insulin sensitivity. 


\section{c. Mitophagy}

Macroautophagy, the process by which altered organelles are recycled, involves several proteins, such as Autophagy-related (Atg) proteins and microtubuleassociated protein-1 Light Chain-3 (LC3) [45]. Mitophagy [46] requires additional proteins such as Phosphatase and TENsin homolog (PTEN)-induced putative kinase 1 (Pink1), Beclin 1, mitochondrial dynamics-related proteins, PI3K, BCL2/Adenovirus E1B 19 kDa Protein - Interacting Protein 3 (BNIP3) and Parkin2. Mfn2 and Heat shock protein $72-k D a(H s p 72)$ are required to label mitochondria for degradation. Inhibition of mitophagy achieved by Hsp72 invalidation in mice results in skeletal muscle insulin resistance, as assessed by hyperinsulinemic-euglycemic clamps [47], while Hsp72 overexpression improves insulin-stimulated skeletal muscle glucose uptake [48]. In obese individuals, no changes in Beclin1, BNIP3 and PI3K [49] are detected. However, Hsp72 mRNA expression in vastus lateralis is inversely correlated with GDR in type 2 diabetic patients [50].

\subsection{Mitochondria and muscle mass}

Skeletal muscle mass is positively correlated with its insulin sensitivity [51-53]. Muscle mass depends on the balance between protein synthesis, which is controlled by the mTOR pathway and protein degradation by the Forkhead box $\mathrm{O}$ (FoxO) pathway [54]. Age-related skeletal muscle mass loss or sarcopenia, has been associated with obesity, giving rise to the sarcopenic obesity concept, in which (i) obesity potentiates aging-related skeletal muscle loss and (ii) aging exacerbates intramuscular fat accumulation and obesity-induced insulin resistance [10,55-57]. 
Mitochondrial dysfunction leads to human skeletal muscle mass loss [58,59]. First, PGC-1a protein is decreased in skeletal muscle of sarcopenic patients [60]. Interestingly, high levels of PGC-1 $\alpha$ and PGC-1 $1 \beta$ protect against catabolic-induced muscle mass loss through FoxO3 repression [61]. Second, promoting fission by reducing Mfn2 expression [62] or overexpressing Drp1 [63] induces skeletal muscle mass loss. Consistently, enabling fusion through Opa1 overexpression [64] or the use of a dominant negative mutant for Drp1 [65] prevents skeletal muscle mass loss. Third, mitochondrial ROS promote muscle sarcopenia in mice [66]. Mitochondriatargeted anti-oxidants rescue muscle atrophy provoked by immobilization protocols $[67,68]$. Finally, pro-mitophagy protein Parkin expression is decreased in aged skeletal muscle [69].

To conclude, deregulation of both primary mitochondrial function and mitochondrial population quality control are key elements in lipid-induced insulin resistance in skeletal muscle (Figure 2). 


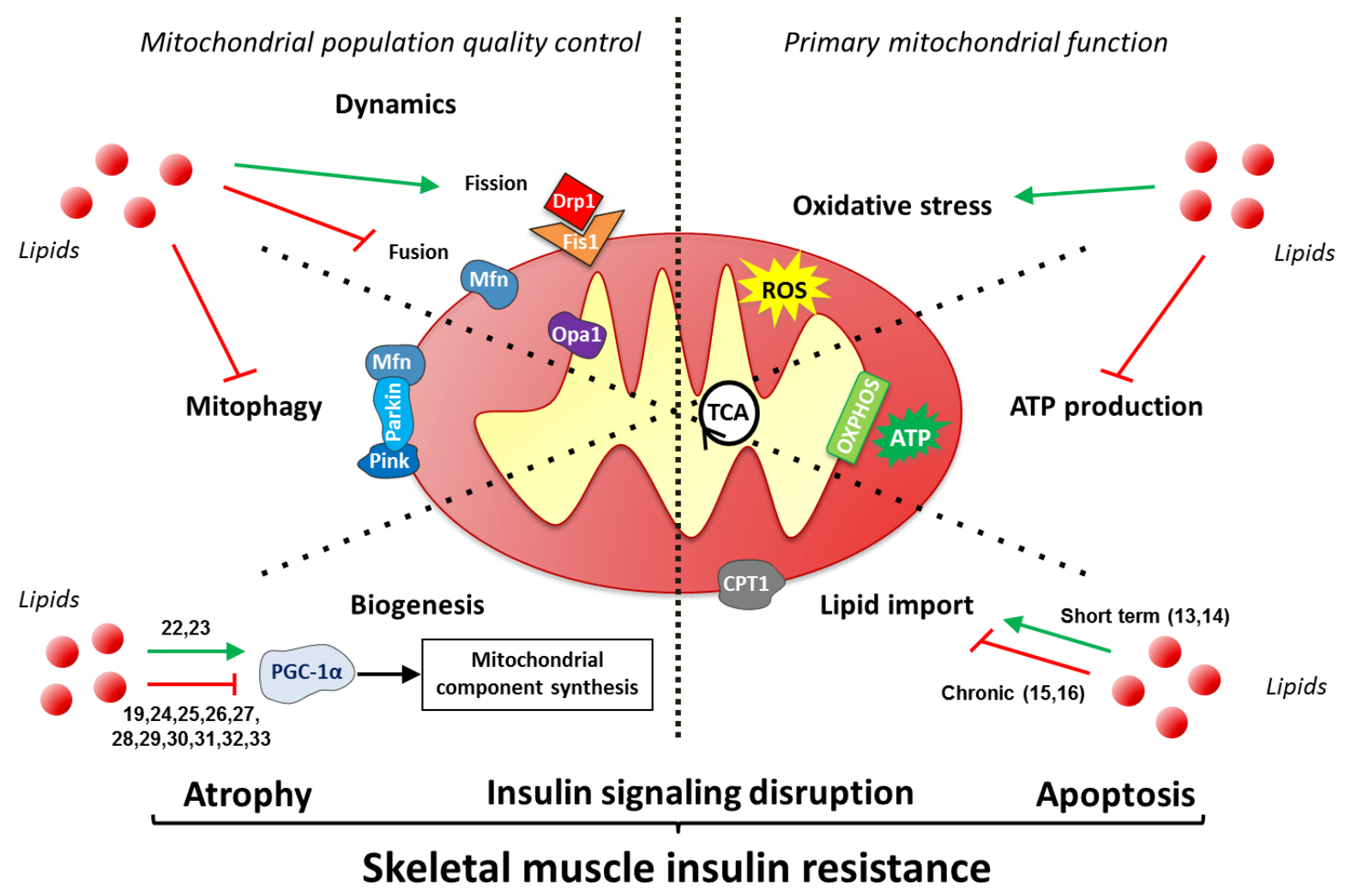

Figure 2: Principal targets of lipid-induced mitochondrial dysfunction and subsequent consequences associated with insulin resistance in skeletal muscle. Both defects in primary function and quality control of mitochondria participate in skeletal muscle insulin resistance through direct modulation of the insulin signaling pathway or indirectly by inducing atrophy and apoptosis. Mitofusin (Mfn), Peroxisome Proliferator-Activated Receptor (PPAR) y Coactivator 1a (PGC-1a), Carnitine PalmitoylTransferase 1 (CPT1), TriCarboxylic Acid (TCA) cycle, Reactive Oxygen Species (ROS), OXidative PHOSphorylation (OXPHOS), Adenosine TriPhosphate (ATP), Optic atrophy 1 (Opa1), Dynamin-related protein 1 (Drp1), mitochondrial Fission 1 protein (Fis1), Phosphatase and TENsin homolog (PTEN)-induced putative kinase 1 (Pink). Green arrows indicate activation, while red lines represent an inhibition. In case of conflicting results, both green arrow and red line are associated with their references. 


\section{The endoplasmic reticulum and skeletal muscle insulin resistance}

The Endoplasmic Reticulum (ER) is an important organelle involved in many processes such as calcium homeostasis, protein folding in the secretory pathway, lipid metabolism and apoptosis. In skeletal muscle, the ER is called sarcoplasmic reticulum and is specialized in calcium homeostasis during excitation-contraction coupling, allowing muscle contraction (Figure 3). Indeed, sarcolemma depolarization induces changes in the Transverse Tubule (TT) voltage sensors, also called DiHydroPyridine Receptors (DHPR), that are transmitted to the Ryanodine Receptors (RyR), which, in turn, release calcium into the cytosol. Calcium binding on the troponin complexes allows the interaction between actin and myosin myofilaments and triggers muscle contraction. Relaxation is achieved when cytosolic calcium has been taken up by the Sarco/Endoplasmic Reticulum Calcium ATPase (SERCA). However, functional triads, i.e. association between a TT and a pair of terminal cisternae of the sarcoplasmic reticulum, require important amounts of ATP. Therefore a large number of mitochondria are localized under the sarcolemma or between myofibers to provide enough energy for proper ER homeostasis, pointing out the importance of both organelles for proper muscle homeostasis [70]. 


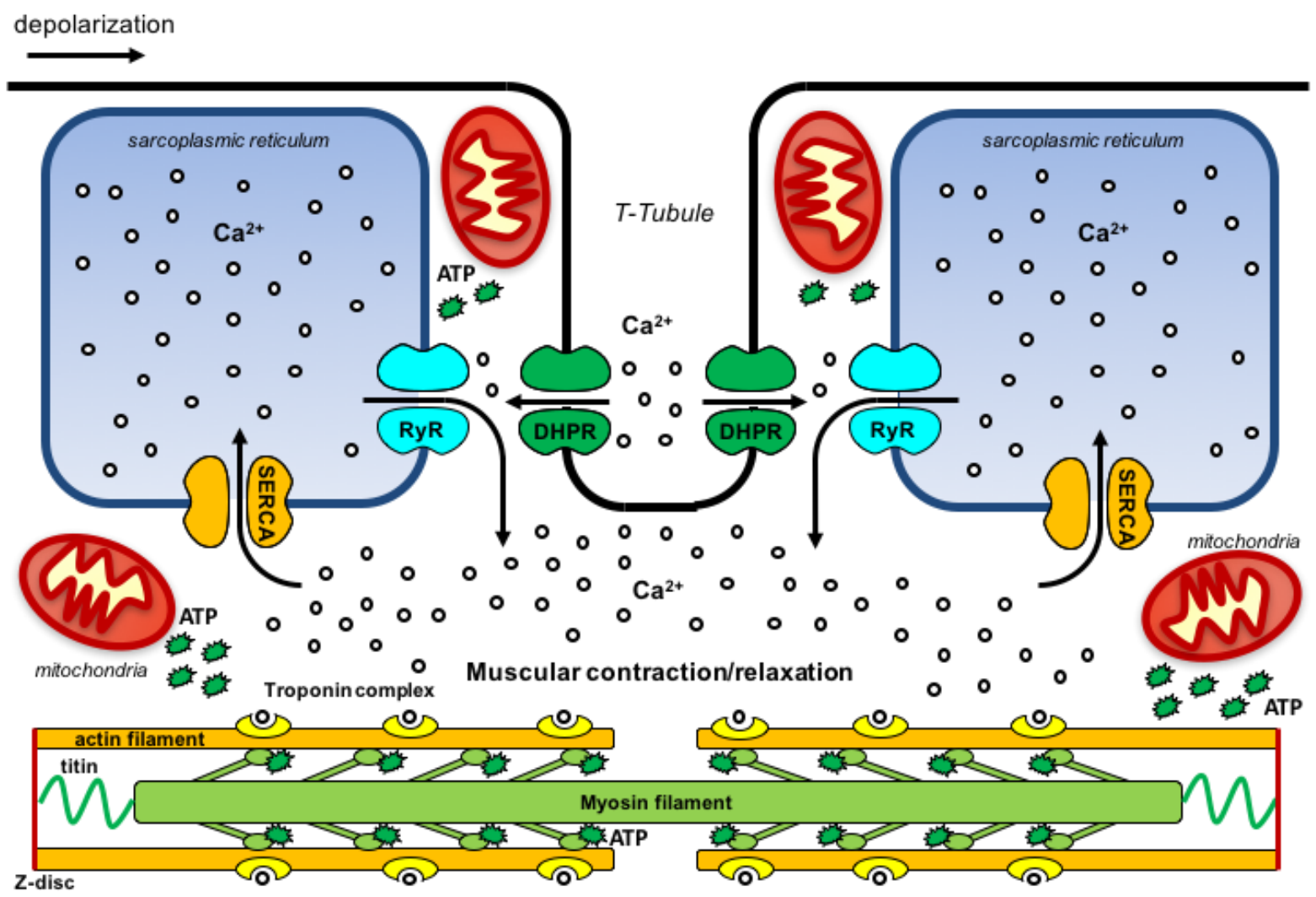

Figure 3: Schematic representation of muscular triad. Mitochondria and sarcoplasmic reticulum enable muscular contraction/relaxation. Transverse Tubule (T-Tubule), Sarco/Endoplasmic Reticulum Calcium ATPase (SERCA), DiHydroPyridine Receptor (DHPR), Ryanodine Receptor (RyR), Adenosine TriPhosphate (ATP).

Disruption of ER homeostasis may participate in skeletal muscle insulin resistance during obesity. In particular, lipid-induced ceramide synthesis in the ER and ER stress-induced Unfolded Protein Response (UPR), through subsequent apoptosis, inflammation, autophagy and skeletal muscle atrophy, contribute to insulin resistance, specifically in skeletal muscle. 


\section{II.1. De novo ceramide synthesis: from physiology to insulin resistance}

Ceramides are sphingolipids belonging to the general family of phospholipids. They are composed of a fatty acid and a sphingosine bound by an amide linkage. Although they are not plasma membrane constituents, ceramides participate indirectly in plasma membrane homeostasis as precursors of sphingomyelins, an important class of plasma membrane phospholipids. Moreover, ceramides are major lipid mediators that modulate the cell cycle and promote apoptosis [71].

Two distinct synthesis pathways lead to ceramide formation. The first consists in the conversion of membrane-localized sphingomyelin into ceramide through the action of sphingomyelinases, which are located at the plasma membrane or in endosome/lysosome compartments [71]. The second is called de novo ceramide biosynthesis and begins in the ER (Figure 4). De novo biosynthesis is initiated by condensation of palmitoyl-CoenzymeA (palmitoyl-CoA) and serine into 3ketosphinganine by Serine PalmitoylTransferase (SPT). Then, 3-KetoSphinganine Reductase (KSR) converts 3-ketosphinganine into sphinganine, which is acylated by Ceramide Synthase (CerS), to produce DiHydroCeramide (DHCer). Finally, the DHCer DESaturase (DES) turns DHCer into ceramide (Figure 4). In physiological conditions, ceramide is then translocated by the ceramide transfer protein to the Golgi apparatus, where it is converted by sphingomyelinase into sphingomyelin, a component of the plasma membrane. Thus, de novo ceramide biosynthesis allows regeneration and expansion of the cell membrane [71].

Some of the enzymes involved in the de novo synthesis can be found in mitochondria, but all are found in the ER [72]. 


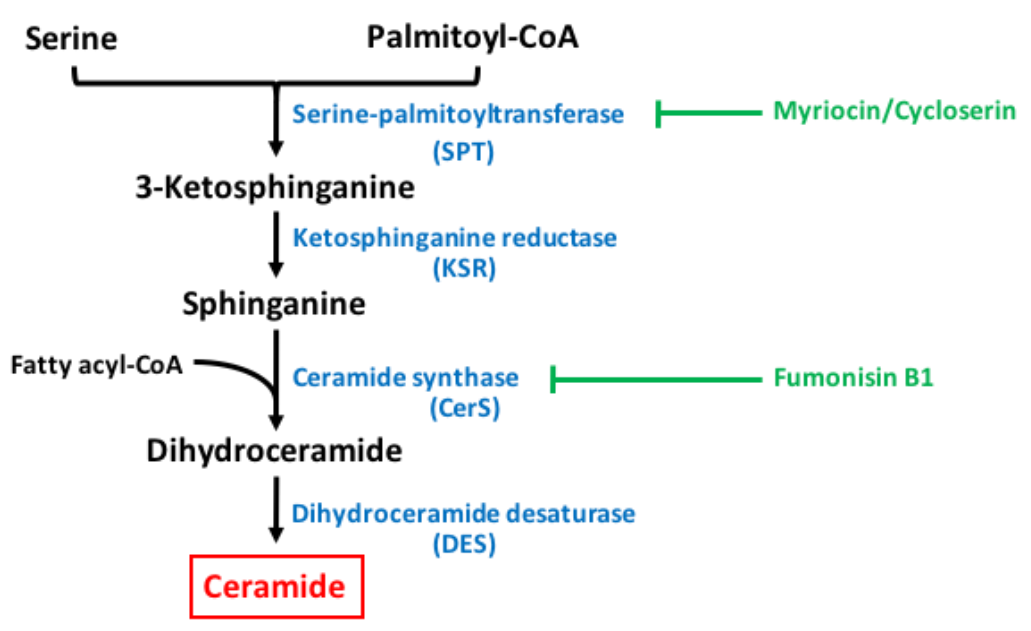

Figure 4: De novo ceramide synthesis pathway in the endoplasmic reticulum. coA: coenzyme A. Myriocin/cycloserine and fumonisin B1 inhibit serinepalmitoyltransferase and ceramide synthase, respectively.

Animal and human studies demonstrate that HFD-feeding or obesity leads to skeletal muscle ceramide accumulation $[10,73]$. Palmitate, transformed through the action of palmitoyl-CoA synthase in active palmitoyl-CoA, the early precursor of de novo ceramide biosynthesis [74], is used to induce ceramide accumulation in skeletal muscle cell lines [10]. Interestingly, palmitate represses insulin-stimulated Akt and GSK3 $\beta$ phosphorylation [10]. Independently, intracellular ceramide accumulation by inhibition of ceramide glucosylation with the glucosylceramide synthase inhibitor DLthreo-1-Phenyl-2-Decanoylamino-3-Morpholino-1-Propanol (PDMP), or inhibition of ceramide deacylation with the ceramidase inhibitor N-Oleoyl-Ethanolamine (NOE), inhibits insulin-stimulated Akt-phosphorylation in C2C12 cells [75]. In addition, activation of $\mathrm{PKC} \zeta$ by ceramide treatment reduces insulin-induced Akt phosphorylation in L6 myotubes [76]. Nevertheless, induction of ceramide accumulation may not entirely recapitulate insulin resistance. For instance, whereas 
overexpression of the ceramide synthase isoforms 1 and 6 in L6 myotubes promotes ceramide accumulation, this also enhances Akt phosphorylation after insulin treatment [77]. Unfortunately, to the best of our knowledge, no human studies have yet investigated whether these enzyme isoforms are modulated in skeletal muscle of obese or diabetic patients.

The pharmacological compounds fumonisin B1 and myriocin/cycloserine inhibit CerS and SPT, respectively, and hence de novo ceramide synthesis (Figure 4). Cycloserine, myriocin and fumonisin B1 prevent palmitate-induced ceramide accumulation in $\mathrm{C} 2 \mathrm{C} 12$ cells [75]. These molecules also restore insulin-induced Akt and GSK3 $\beta$ phosphorylation impaired by palmitate [75]. In mice, subcutaneous injection of myriocin during the last 4 weeks of a 6 week-saturated fat diet reverses ceramide accumulation in quadriceps muscle and glucointolerance [78]. Consistently, daily intraperitoneal myriocin injections in the last four weeks in mice fed a HFD for a total 12-week period protects mice against insulin resistance and glucose intolerance, associated with decreased ceramide accumulation and improved of insulin signaling in gastrocnemius muscle [79]. Physical activity is also beneficial as exercise prevents ceramide accumulation and subsequent impairment of insulin resistance in ex vivo rodent palmitate-treated soleus muscle [80]. Interestingly, fumonisin B1 treatment has similar effects as exercise [80].

\section{II.2. ER stress in skeletal muscle insulin resistance}

An important function of the ER is to properly fold newly synthesized proteins, which will either stay in the organelle or follow the secretory pathway. ER chaperone proteins belong to the family of the Glucose-related proteins (Grp). Some examples 
are Grp78 (also called Binding-immunoglobulin Protein (BiP)), Grp94, Grp170 and 150 kDa-Oxygen-Related Protein (ORP150). Impairment of calcium homeostasis and redox buffer capacity [81] as well as ceramide accumulation [10] lead to an imbalance between the ER folding capacity and the amount of luminal proteins that require to be folded, triggering a specific stress response called UPR (Figure 5). Under normal conditions, Inositol-Requiring Enzyme 1 (IRE1), Protein kinase R-like ER Kinase (PERK) and Activating Transcription Factor 6 (ATF6), three proteins inserted in the ER membrane, are bound to the foldase BiP. When ER stress occurs, $\mathrm{BiP}$ is released to assist in protein folding. As a consequence, the UPR is activated through oligomerisation of IRE1 and PERK as well as ATF6 translocation to the Golgi apparatus. IRE1, which has endonuclease activity, processes unspliced X-box binding-1 (uXBP1) into spliced XBP1 (sXBP1). PERK phosphorylates the eukaryotic translation Initiation Factor $2 \alpha$ (elF2 $\alpha$ ), hence inducing translation inhibition and ATF4 activation. ATF6 is cleaved by Site-1 and Site-2 Proteases (SP1/SP2), which are localized in the Golgi apparatus membrane. sXBP1, ATF4 and cleaved ATF6 translocate to the nucleus, bind to specific promoters controlling the expression of chaperones, antioxidant enzymes and enzymes involved in the ER-Associated Protein Degradation (ERAD) process in order to counterbalance protein overload. In case of sustained stress, UPR may also activate apoptosis and proinflammatory pathways [81]. More information on ER stress and UPR is available in these reviews $[82,83]$. 


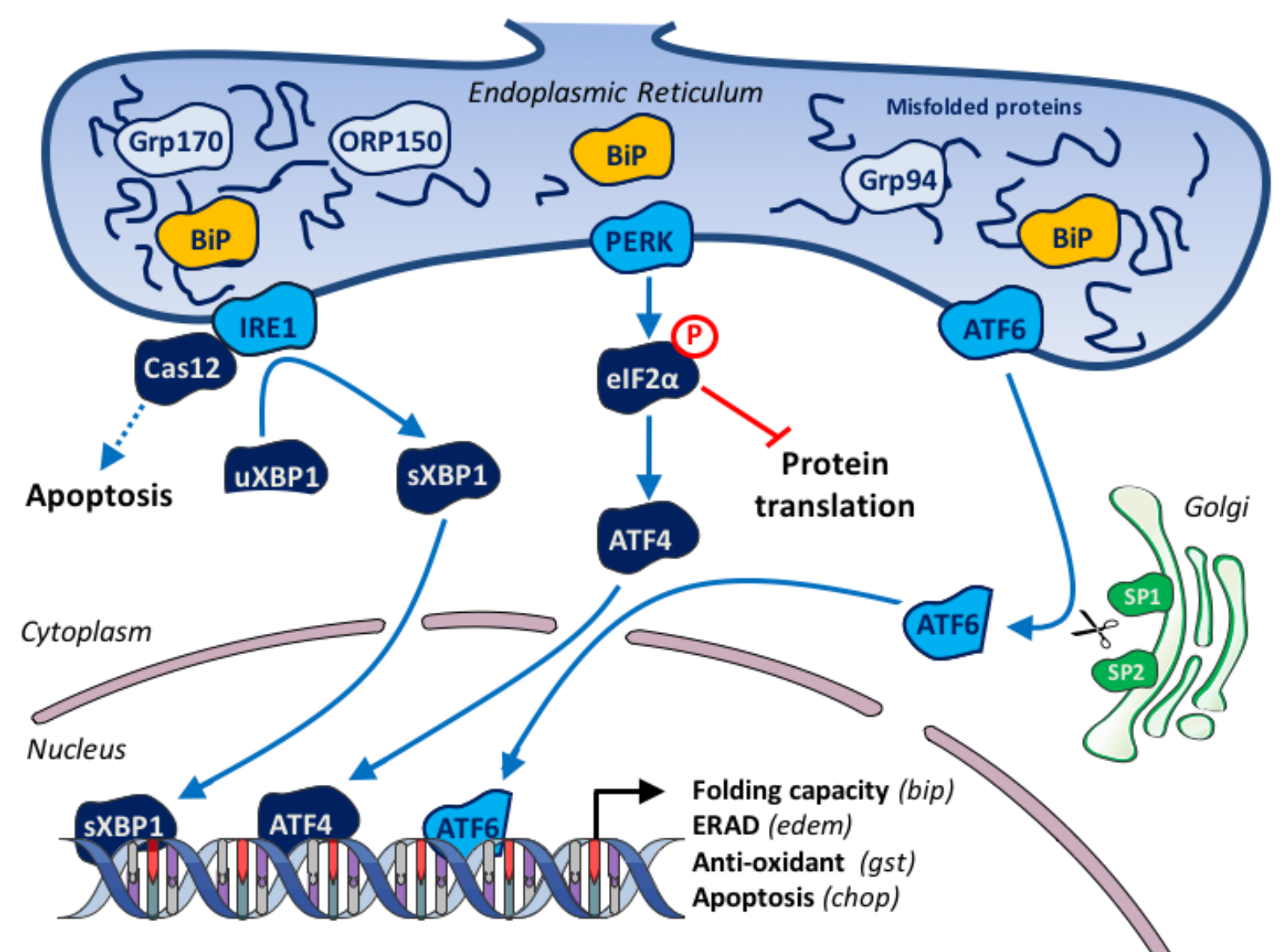

Figure 5: Schematic view of the Unfolded Protein Response. Accumulation of unfolded proteins in the endoplasmic reticulum lumen leads to dissociation of the Binding immunoglobulin Protein (BiP) from Inositol-Requiring Enzyme-1 (IRE1), Protein kinase R-like ER Kinase (PERK) and Activating Transcription Factor 6 (ATF6). IRE1 converts unspliced X-box Binding Protein-1 (uXBP1) into its spliced form sXBP1; PERK activates eukaryotic translation Initiation Factor $2 \alpha(\mathrm{elF} 2 \alpha)$, which promotes Activating Transcription Factor 4 (ATF4) and inhibits protein translation; ATF6 translocates to the Golgi apparatus where it is processed by Site-1 and Site-2 Proteases (SP1/SP2). Finally, sXBP1, ATF4 and ATF6 bind to target gene promoters, leading to transcriptional activation and synthesis of proteins which will improve the folding capacity, reduce oxidative stress and activate the ER-Associated protein Degradation (ERAD) process. If sustained, UPR can trigger inflammation and 
apoptosis. Glucose-related protein (Grp) 94 (Grp94) and 170 (Grp170), 150 kDa Oxygen-Related Protein (ORP150), CCAAT/enhancer binding protein (C/EBP) HOmologous Protein (CHOP)

In skeletal muscle of HFD-fed and genetically (ob/ob) obese mice, UPR is activated and promotes insulin resistance [84-87]. Palmitate, commonly used to induce insulin resistance in muscle cell models, activates UPR [88,89]. Of note, non-lipidic ER stressors such as the $\mathrm{N}$-glycosylation inhibitor tunicamycin $[84,86,90-94]$ and the SERCA inhibitor thapsigargin $[86,87,90,92,94]$, reproduce ER stress-induced insulin resistance in myotubes.

IRE1 indirectly activates c-Jun N-terminal Kinase (JNK) [95], which, in turn, phosphorylates the IRS on serine residues [96], reducing insulin signaling. The IRE1 pathway, and more specifically sXBP1 [85], has also been shown to mediate insulin resistance through inhibition of PI3K signaling by increasing expression of Skeletal muscle and Kidney-enriched Inositol polyphosphate Phosphatase (SKIP), which binds to BiP in absence of insulin and absence of ER stress [97]. Moreover, glucosamine, a glucose metabolite generated during hyperglycemia, triggers ER stress-induced insulin resistance, and ATF6 silencing is able to abolish the inhibitory effects of glucosamine on insulin signaling [98].

Crosstalks between UPR signaling, Extracellular signal-Regulated Kinase (ERK) and AMP-activated Kinase (AMPK) modulate skeletal muscle insulin resistance [84,89,91,94,99]. ER stress activates ERK and inhibits AMPK in rodent myotubes $[84,91,94]$. The ERK inhibitor U0126 restores insulin signaling and glucose uptake through AMPK activation in tunicamycin-treated myotubes from soleus muscle of 
$d b / d b$ mice [91]. Moreover, U0126 has no effect when cells are transfected with siRNA targeting AMPK [91]. Interestingly, ERK inhibition also prevents PERK and IRE-1 phosphorylation in tunicamycin-treated myotubes [91], but the role of AMPK in this crosstalk was not investigated. Nevertheless, the AMPK activators AICAR and A769662 reverse both insulin resistance and ER stress caused by palmitate treatment in myotubes, while AMPK inhibition with compound $\mathrm{C}$ and overexpression of a dominant negative AMPK form exacerbate insulin resistance [89]. In vivo, treatment with the AMPK activator Low Molecular Weight Fucoidan (LMWF) alleviates ER stress and insulin resistance in skeletal muscle of $d b / d b$ mice [99]. Interestingly, ob/ob mice treated with the anti-cancer molecule bortezomib, which is primarily a proteasome inhibitor, display improved insulin sensitivity, lower muscle UPR activation and higher Akt activation upon insulin treatment [100]. The same beneficial effects of bortezomib were observed in palmitate-treated C2C12 myotubes [100]. AMPK silencing abolishes bortezomib action [100], suggesting again that AMPK activation reduces ER stress and improves skeletal muscle insulin sensitivity.

Calcium is another potent modulator of ER stress-induced insulin resistance in skeletal muscle. Indeed, an increase in SERCA2b expression by the natural compound jaceosidin restores insulin signalling in insulin-resistant $\mathrm{C} 2 \mathrm{C} 12$ myotubes, as assessed by increased phosphorylation of IR- $\beta$, IRS-1 and Akt [101]. This is associated with a lower induction of $\mathrm{BiP}$ and CCAAT/enhancer binding protein (C/EBP) HOmologous Protein (CHOP) as well as eiF2 $\alpha$ phosphorylation [101]. Consistently, daily intraperitoneal injection of jaceosidin during 20 days restores insulin-stimulated Akt phosphorylation and reduces $\mathrm{CHOP}$ protein and eiF2 $\alpha$ phosphorylation in skeletal muscle from 16-week HFD-fed mice [101]. Finally, 
Calcium/calmodulin-dependent protein Kinase Kinase 2 (CaMKK2) is required for the beneficial effects of the AMPK activator glyceollin on insulin sensitivity in $d b / d b$ mice [87].

Protein Tyrosine Phosphatase 1B (PTP1B), which is located in the ER membrane, is a negative regulator of insulin signaling by dephosphorylating tyrosine residues of IR and IRS1 [102]. ptp1b gene silencing in obese mice alleviates skeletal muscle glucose intolerance and reduces elF2 $\alpha$ phosphorylation, but does not affect other ER stress-related pathways [93]. Consistently, ptp1b knockdown in HFD-fed mice prevents both ER stress and skeletal muscle insulin resistance [103].

In obese patients, ectopic lipid accumulation triggers muscle inflammation, which in turn contributes to impaired insulin sensitivity $[104,105]$. The pro-inflammatory transcription factor Nuclear Factor kappa B (NF-kB) is activated upon tunicamycin treatment and in gastrocnemius muscle of HFD-fed mice [103]. In addition, both treatment with the chemical chaperone TauroUrsoDeoxyCholic Acid (TUDCA), which enhances protein stabilization directly or through association with other chaperones [106], and knockdown of UPR genes counteract LipoPolySaccharide (LPS) and InterLeukin-1 $(\mathrm{IL}-1 \beta)$-induced inflammation in primary muscle cells [107]. This is accompanied by a restoration of glucose uptake and phosphorylation of IR and IRS1 upon insulin treatment [107].

A few studies have proposed that the UPR is not involved in skeletal muscle insulin resistance [88,108-110]. Nevertheless, the chemical chaperones 4-Phenyl Butyric Acid (PBA), which reduces protein aggregation by binding to hydrophobic segments of misfolded proteins [106], and TUDCA restore insulin sensitivity in ob/ob mice, through improvement of skeletal muscle glucose uptake as revealed by 
hyperinsulinemic euglycemic clamp assays [111]. Consistently, mice overexpressing the ER chaperone ORP150 display better insulin signaling in skeletal muscle [112]. Moreover, daily gavage with the chemical chaperone 3-Hydroxy-2-Naphthoic Acid (3HNA) during 2 weeks restores insulin-stimulated Akt phosphorylation in soleus muscle from $o b / o b$ mice [113]. In humans, there is no evidence of alterations in ER chaperone expression and function in metabolic disorders. In addition, the UPR is not activated in skeletal muscle of humans after a 6-week hypercaloric fat-enriched nutritional program [114]. Nevertheless, total area under the glucose curve after an oral glucose tolerance test and the Matsuda index, which reflects hepatic and muscular insulin sensititvity, remain unchanged [114]. Overall, there are no human studies testing a more relevant paradigm for the pathology of type 2 diabetes.

\section{II.3. ER dysfunction-induced skeletal muscle mass loss}

Compared to 6-month old rats, skeletal muscle from 32-month old sarcopenic animals display increased BiP, CHOP and activated caspase-12 expression [115]. Moreover, 10-week HFD-feeding enhances the sarcopenic phenotype of hindlimb muscle from 25-month old rats [10].

Both tunicamycin and thapsigargin, through Akt inactivation, block mTOR activation in muscle cells [90], hence inducing anabolic resistance. Moreover, protein synthesis rates are decreased in ER-stressed insulin resistant skeletal muscle of obese sarcopenic rats and in palmitate-treated myotubes, despite an unchanged mTOR pathway [10]. This could be explained by elF2 $\alpha$-dependent inhibition of protein translation [10]. Besides, mTOR could also modulate UPR as rapamycin-induced 
mTOR inhibition alleviates ER stress in tunicamycin-treated L6 myotubes [92]. This is associated with improved insulin sensitivity [92].

Apoptosis and autophagy also participate in muscle mass loss (Figure 6). ER stress activates autophagy by enhancing expression of both Atg12 mRNA and protein through elF2a phosphorylation [116]. Sustained ER stress contributes to protein degradation through protein ubiquitination [117] and induction of apoptosis [118], mediated by caspase-3 [119] and endonuclease G [120]. Interestingly, caspase inhibitors as well as the ceramide synthase inhibitor fumonisin prevent ceramide accumulation and apoptosis and restore insulin sensitivity induced by palmitate treatment of L6 cells, hence the "lipoapoptosis" concept [121].

Healthy muscle

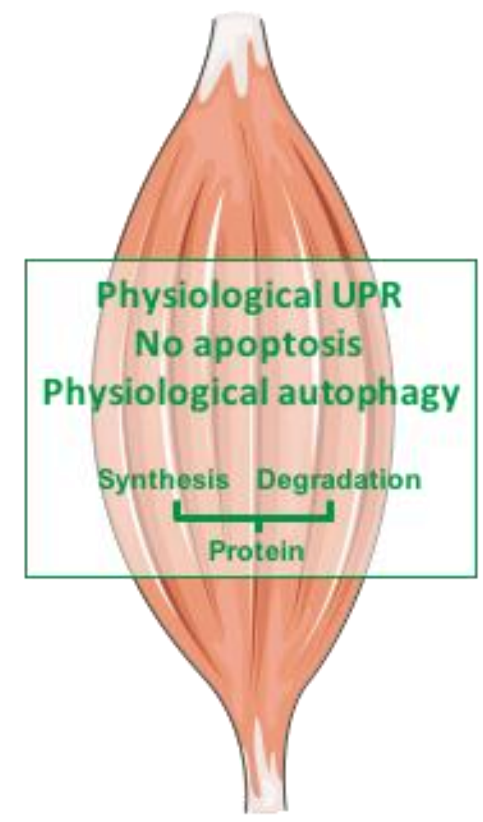

Sarcopenia

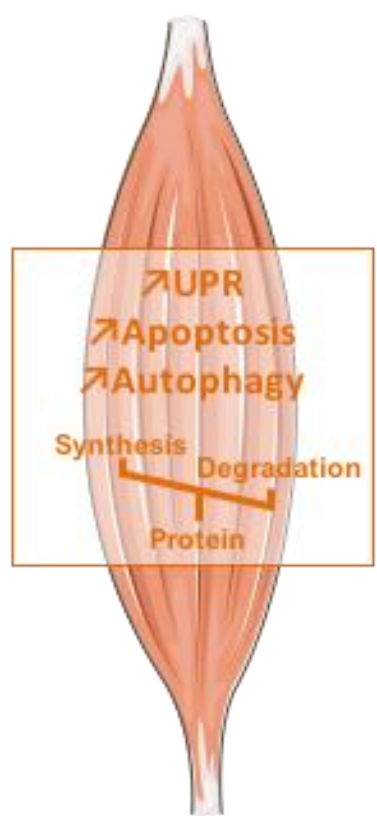

Sarcopenic obesity

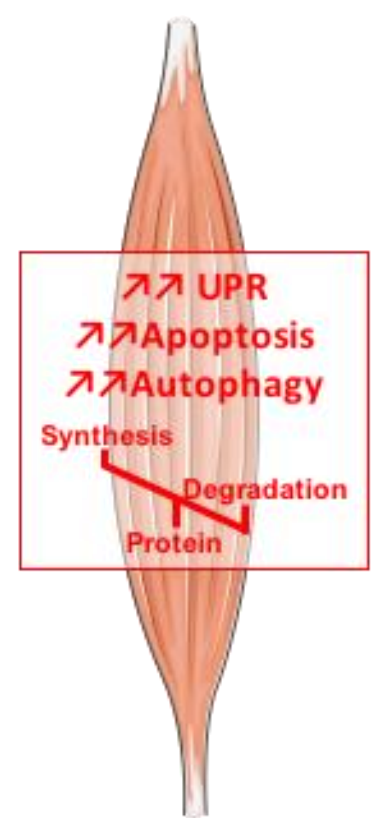


Figure 6: Schematic representation of skeletal muscle from healthy, sarcopenic and obese sarcopenic patients. Unfolded Protein Response (UPR), apoptosis and autophagy increases and dysregulated balance between protein synthesis and degradation occurs with age and with obesity, hence promoting atrophy and insulin resistance.

Overall, ER dysfunctions contribute to skeletal muscle insulin resistance through activation of several signaling pathways leading to tissue inflammation, atrophy and impairment of insulin signaling (Figure 7).

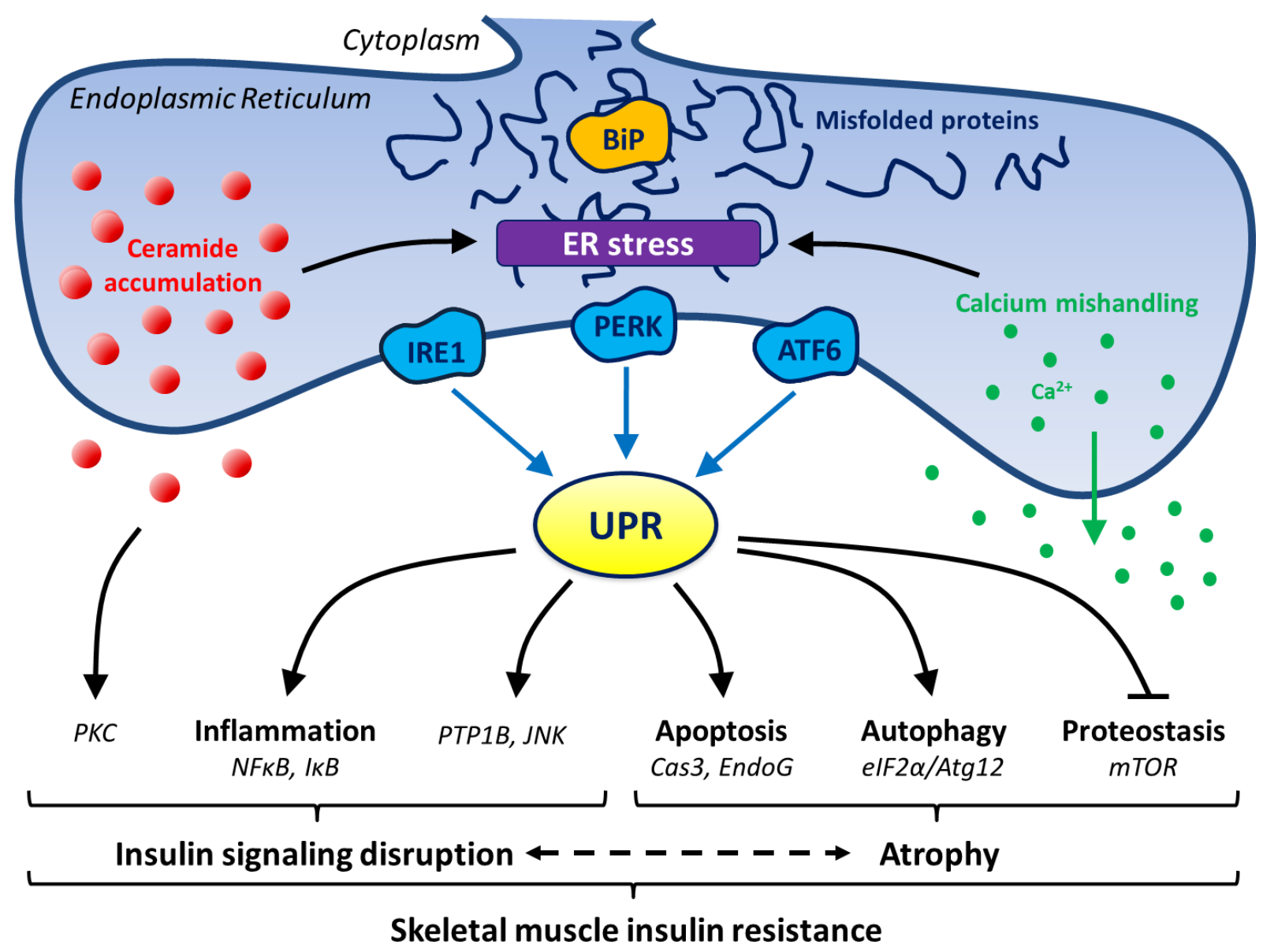

Figure 7: Principal ER effectors leading to skeletal muscle lipid-induced insulin resistance. Lipids induce de novo ceramide production, calcium mishandling and ER stress, all leading to the Unfolded Protein Response (UPR). In turn, UPR activation 
directly modifies insulin signaling through Protein Tyrosine Phosphatase 1B (PTP1B), c-Jun N-terminal Kinase (JNK) and inflammation activation. The UPR promotes muscle atrophy by activating apoptosis and autophagy and inhibiting protein synthesis. Therefore, the UPR contributes directly and indirectly to skeletal muscle insulin resistance. Besides, ceramide accumulation and Protein Kinase C (PKC) activation promote insulin resistance. Binding immunoglobulin Protein (BiP), InositolRequiring Enzyme-1 (IRE1), Protein kinase R-like ER Kinase (PERK), Activating Transcription Factor 6 (ATF6), eukaryotic translation Initiation Factor 2a (elF2a), Nuclear Factor kappa B (NFkB), Inhibitor of NFkB (IKB), Caspase-3 (Cas3), Endonuclease G (EndoG), mammalian Target Of Rapamycin (mTOR), Autophagyrelated $12(\operatorname{Atg} 12)$.

\section{Therapeutics improving mitochondrial and ER functions}

Mitochondria and ER are two important and indissociable organelles required for proper insulin sensitivity. Changes in lifestyle, bariatric surgery and pharmacological approaches, which are currently used to improve insulin sensitivity, have mainly shown impact on mitochondrial function. Recently, strategies to modulate ER homeostasis have also been tested in humans.

\section{Reduction in calorie intake}

Calorie restriction performed in insulin-resistant patients improves insulin sensitivity [122-124]. Surprisingly, this was not associated with improved mitochondrial function [123], but rather with reductions in Succinate DeHydrogenase (SDH) activity [122] or mitochondrial size [124]. Such observations support the idea that mitochondria may 
not be the primary cause leading to skeletal muscle insulin resistance. Rather, the beneficial effects of calorie restriction could be mediated by a reduction in intramuscular lipid intermediates such as DAG [122], which in turn activates PKC and promotes insulin resistance.

\section{Bariatric surgery}

Sustained weight loss can also be achieved in obese patients who undergo bariatric surgery such as Roux-en-Y Gastric Bypass (RYGB) or sleeve gastrectomy procedures. Insulin sensitivity improves in these patients but, as for calorie restriction, the contribution of mitochondria seems to be limited as mitochondrial content assessed by measurement of cardiolipin content, OXPHOS protein expression [125] and maximal respiration [126] remain similar to the preoperative conditions. Nevertheless, RYGB-induced weight loss increases contribution of complex I to maximal OXPHOS respiration [125]. Bariatric surgery also increases Mfn2 expression $[127,128]$, which could be related to increased PGC-1a expression [127]. Mfn2 expression is positively correlated with insulin sensitivity and glucose oxidation [128]. This highlights that, in addition to mitochondrial mass, a properly functioning mitochondrial network is likely important in the regulation of skeletal muscle oxidative capacity. It also suggests that Mfn2 could regulate other cellular functions (e.g. endoplasmic reticulum).

\section{Physical exercise}

The beneficial effects of exercise on skeletal muscle mitochondrial function are well described and have been recently reviewed [129]. Overall, despite the heterogeneity 
of protocols in terms of type of exercise, frequency and duration, all studies pointed out that physical activity in obese and/or diabetic patients triggers mitochondrial biogenesis, improves mitochondrial function, reduces $\mathrm{H}_{2} \mathrm{O}_{2}$ production and increases fatty acid oxidation. Mitochondrial networking may also be upregulated by exercise as reductions in phosphorylated serine 616 Drp1, its active form, and a trend towards an increase in Mfn1/2 expression were observed in exercised obese subjects [130]. Although highlighting a therapeutic interest in regulating mitochondrial dynamics, regulators of this process [131] have not been tested in clinical trials yet.

\section{Pharmacological approaches}

Thiazolidinediones, such as rosiglitazone and pioglitazone, are PPAR-y agonists which improve skeletal muscle insulin sensitivity in obese and type 2 diabetic patients. Rosiglitazone treatment increases PGC-1 $\alpha$ [28], PPAR $\beta / \delta$ [28] and UnCoupling Protein 3 (UCP3) [132] expression. However, citrate synthase activity [133] and expression of mitochondrial respiratory chain complexes remained unchanged $[28,132,133]$. Mitochondrial efficiency did not correlate with insulin sensitivity [134], despite increases in SDH activity [28]. Overall, it seems that an amelioration of mitochondrial function by thiazolidinediones does not mediate their actions to improve skeletal muscle sensitivity, reinforcing the conclusion that mitochondrial dysfunction may not be the cause but rather a consequence of glucose mishandling. Moreover, thiazolidinediones may exert indirect effects, notably through the adiponectin/AdipoR1/AMPK pathway $[135,136]$, which may contribute to improve skeletal muscle insulin sensitivity. 
Another strategy emerged in the early 2000 s thanks to the discovery of $3,5,4^{\prime}$ trihydroxystilbene, better known as resveratrol. This polyphenol activates SIRT1, enhancing deacetylation and activation of PGC-1a. While its beneficial effects on insulin sensitivity have been documented in vitro and in vivo, clinical studies remain scarce [137] and its impact on skeletal muscle has not been extensively explored. Nevertheless, obese subjects that received one-month resveratrol treatment presented better insulin sensitivity, higher muscle PGC-1a and OXPHOS gene expression along with increased mitochondrial fatty acid utilization [138]. However, in another study performed in diabetic patients, resveratrol did not improve peripheral insulin sensitivity while ex vivo mitochondrial function measured in muscle biopsies was improved [139]. The absence of amelioration in insulin sensitivity was assumed by the authors to be due to resveratrol-metformin interaction, based on a positive correlation found between the plasma level of resveratrol metabolite dihydroresveratrol and the metformin dose used in these diabetic patients [139].

Consistent with the observations made in mice [111], oral administration of the chemical chaperone TUDCA, enhanced in vivo glucose rate of disappearance measured by hyperinsulinemic-euglycemic clamp procedure in obese insulinresistant subjects [140]. After insulin injection, levels of phosphorylated IRS and Akt were higher in TUDCA-treated obese patients compared with the placebo group [140]. However, no changes were observed in the UPR-related pathway, questioning the molecular mechanisms underlying the effects of this bile acid [140]. Future studies are required to test whether more specific UPR inhibitors [141] improve skeletal muscle insulin sensitivity. 
The effects of different interventions that focus on insulin sensitivity in humans on mitochondria and ER modulation are summarized in Table 2. While further analyses are required to clearly identify the role of ER stress and mitochondria in humans, clinical studies indicate that mitochondrial dysfunction is rather a consequence than a cause of skeletal muscle insulin resistance.

\section{Research and therapeutic perspectives}

Based on cellular and animal models, it seems that both mitochondria and ER function improvement may augment insulin sensitivity in muscle cells although clinical relevance in humans remains to be further evaluated. Recent studies focussed on the physical interaction between these organelles to understand how their communication may impact on insulin sensitivity. For instance, overexpression of the mitochondrial DNA repair protein human 8-OxoGuanine DNA N-Glycosylase 1 (hOGG1) [117] prevents both mitochondrial DNA damage and ROS production as well as activation of the UPR $[142,143]$. Consistently, hOGG1 overexpression also protects against palmitate-induced insulin resistance in myotubes [142].

Recent observations indicate that mitochondrial membranes are tightly associated with the ER. Indeed, Percoll gradient isolation of mitochondria co-segregated ER-like membranes which are designated as "Mitochondria-Associated (endoplasmic reticulum) Membranes" (MAMs). Most MAM proteins are ER-related proteins: lipidsynthesizing enzymes, NADPH-cytochrome $\mathrm{c}$ reductase, redox regulation enzymes such as oxidoreductase 1a (Ero1a), sorting proteins such as Phosphofurin Acidic Cluster Sorting protein 2 (PACS2), chaperones such as Grp75, receptors such as $\sigma 1$ receptor $(\sigma 1 \mathrm{R})$, itinerant proteins such as B-cell receptor-Associated Protein 31 
(BAP31), protein kinases, such as PERK, and calcium handling proteins such as IP3R1 (for review [144,145]). Mitochondrial proteins are also found in this fraction, such as mitochondria dynamics and morphology-related proteins (Mfn1, Mfn2 and Drp1) as well as the Voltage-Dependent Anion Channel (VDAC) (Figure 8).

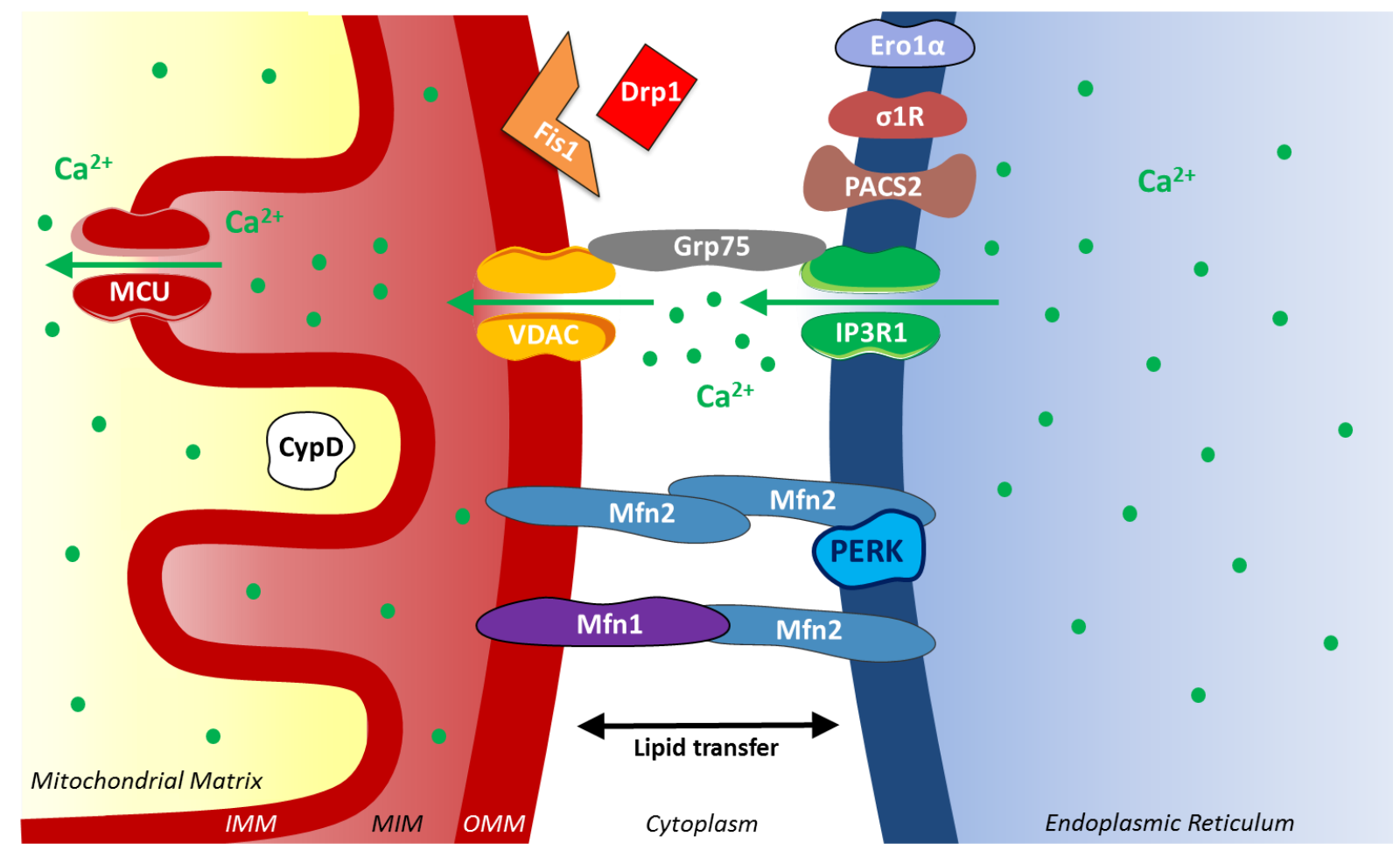

Figure 8: Mitochondria-associated membranes (MAMs). Proteins identified as parts of the MAM complex: Inositol-TriPhosphate Receptor 1 (IP3R1), Glucose-related protein $75 \mathrm{kDa}$ (Grp75), Voltage-Dependent Anion Channel (VDAC) and Cyclophilin D (CypD), Mitofusins 1 and 2 (Mfn1, Mfn2), Dynamin-related protein 1 (Drp1), Fission protein 1 (Fis1), o1 Receptor ( $\sigma 1 \mathrm{R})$, Phosphofurin Acidic Cluster Sorting protein 2

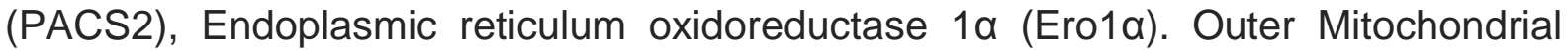
Membrane (OMM), Mitochondrial InterMembrane space (MIM), Inner Mitochondrial Membrane (IMM). Mitochondrial Calcium Uniporter (MCU). 
The effects of MAMs on insulin resistance and metabolic diseases have mainly been studied in the liver (for review: $[146,147]$ ), yelding opposite results regarding the role of MAMs in hepatic insulin sensitivity [148-151]. On the one hand, electron microscopy showed that hepatic MAM formation is increased in ob/ob or HFD-fed mice (60\% fat calories). In these conditions, MAMs could drive mitochondrial calcium accumulation, and lead to mitochondrial dysfunction and ultimately insulin resistance [151]. On the other hand, ob/ob mice or mice fed with HFD/High Sucrose display lower MAMs, but this time, MAMs are detected with the in situ Proximity Ligation Assay (PLA) technique [150]. Despite indirect data $[37,152]$, there is no evidence demonstrating the existence of MAMs in skeletal muscle. If further studies prove the reality of MAMs in skeletal muscle, it will then be interesting to determine whether MAM modulation, by targeting cyclophilin D for instance, improves insulin resistance through mitochondrial and ER functions in skeletal muscle.

\section{Conclusion}

The causal role of either mitochondria and/or ER in lipid-induced insulin resistance of skeletal muscle remains a matter of debate. However, as illustrated figure 9 , it is obvious that both organelles, particularly inseparable in skeletal muscle homeostasis, are impacted by lipids and trigger complex and numerous signaling cascades that reinforce the skeletal muscle insulin resistance phenotype, either by directly affecting insulin signalling or indirectly promoting muscle atrophy. Although not yet established 
in skeletal muscle, MAM modulation could bring novel views on cellular physiology and offer new therapeutic opportunities for the treatment of obesity-related disorders.

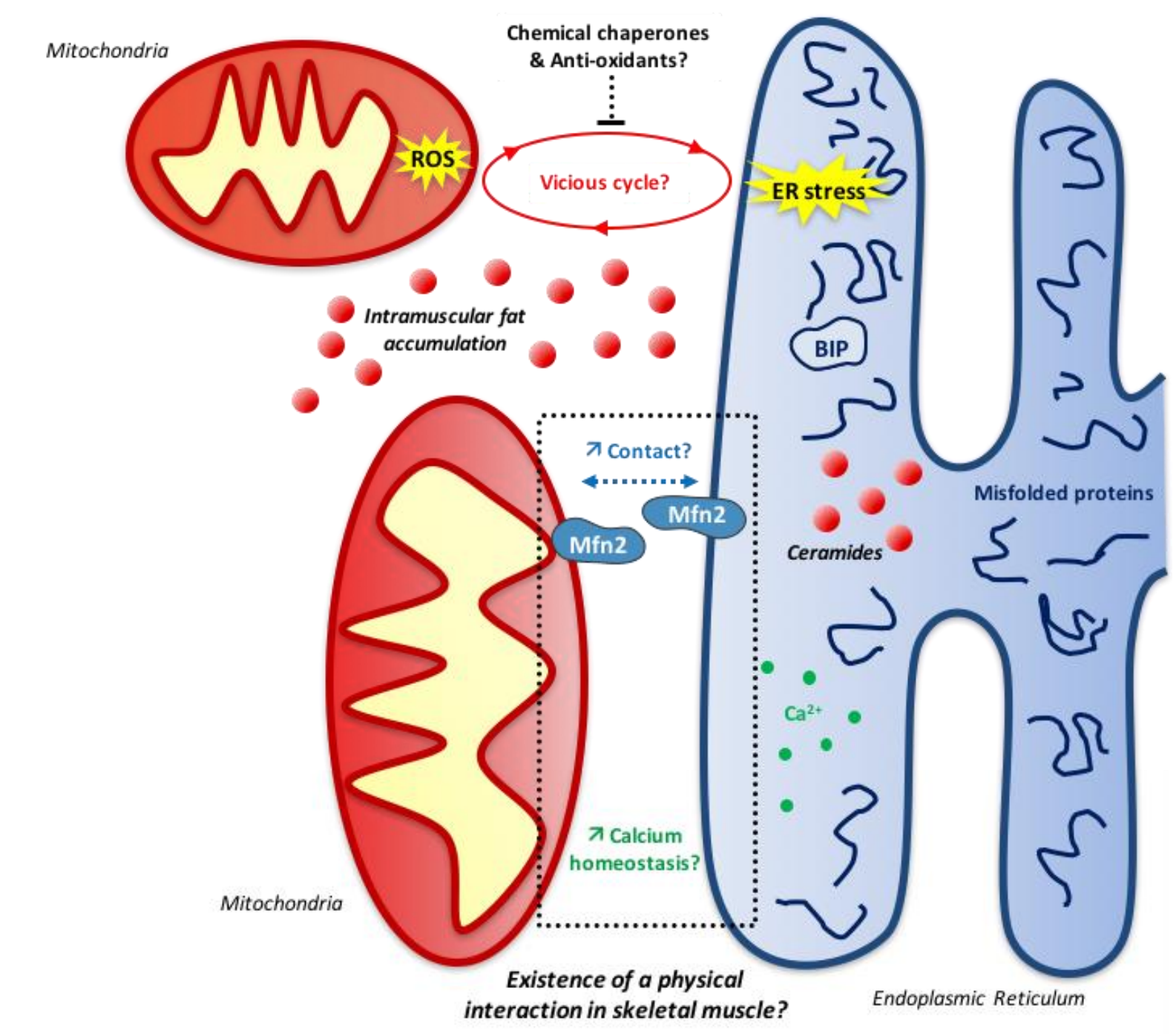

Figure 9: Hypothetical model of ER and mitochondria communication and related potential targets to enhance skeletal muscle insulin sensitivity. Mitofusin 2 (Mfn2), Reactive Oxygen Species (ROS), Endoplasmic Reticulum (ER), Binding Immunoglobulin Protein (BIP). 
Table 1: Mitochondria and ER-related proteins involved in skeletal muscle insulin resistance.

\begin{tabular}{|c|c|c|c|}
\hline Protein name & Acronym & Localization & Function \\
\hline $\begin{array}{l}150 \text { kDa-oxygen-related } \\
\text { Protein }\end{array}$ & ORP150 & $\begin{array}{l}\text { Endoplasmic } \\
\text { reticulum }\end{array}$ & Protein folding \\
\hline $\begin{array}{l}\text { Activating Transcription } \\
\text { Factor } 4\end{array}$ & ATF4 & Cytoplasm & $\begin{array}{l}\text { Transcription factor of UPR } \\
\text { signalling }\end{array}$ \\
\hline $\begin{array}{l}\text { Activating Transcription } \\
\text { Factor } 6\end{array}$ & ATF6 & $\begin{array}{l}\text { Endoplasmic } \\
\text { reticulum } \\
\text { membrane }\end{array}$ & ER stress sensor \\
\hline Akt or Protein Kinase B & Akt or PKB & $\begin{array}{l}\text { Cytoplasm \& } \\
\text { Sarcolemmal } \\
\text { membrane }\end{array}$ & $\begin{array}{l}\text { Increase of glycogen } \\
\text { production, glycolysis \& } \\
\text { glucose uptake }\end{array}$ \\
\hline AMP-activated Kinase & AMPK & Cytoplasm & Kinase \\
\hline Autophagy-related proteins & Atg & Cytoplasm & Promotion of autophagy \\
\hline Beclin1 & & Cytoplasm & Promotion of mitophagy \\
\hline $\begin{array}{l}\text { BCL2/Adenovirus E1B } 19 \\
\text { kDa Protein-Interating } \\
\text { Protein } 3\end{array}$ & BNIP3 & Cytoplasm & Promotion of mitophagy \\
\hline c-Jun N-terminal Kinase & JNK & Cytoplasm & Kinase \\
\hline $\begin{array}{l}\text { Calcium/calmodulin- } \\
\text { dependent protein Kinase } \\
\text { Kinase } 2\end{array}$ & CaMKK2 & Cytoplasm & Kinase \\
\hline $\begin{array}{l}\text { Carnitine } \\
\text { PalmitoylTransferase } 1\end{array}$ & CPT1 & $\begin{array}{l}\text { Outer } \\
\text { mitochondrial } \\
\text { membrane }\end{array}$ & $\begin{array}{l}\text { Entry of long-chain acyl- } \\
\text { coenzyme A into mitochondria }\end{array}$ \\
\hline Caspase-3 & Cas3 & Cytoplasm & Main pro-apoptotic effector \\
\hline Ceramide synthase & CerS & $\begin{array}{l}\text { Endoplasmic } \\
\text { reticulum }\end{array}$ & Dihydroceramide formation \\
\hline Cyclophilin D & CypD & $\begin{array}{l}\text { Mitochondrial } \\
\text { matrix }\end{array}$ & $\begin{array}{l}\text { Modulation of calcium } \\
\text { homeostasis }\end{array}$ \\
\hline Dihydroceramide desaturase & DES & $\begin{array}{l}\text { Endoplasmic } \\
\text { reticulum }\end{array}$ & Ceramide formation \\
\hline DiHydroPyridine Receptor & DHPR & $\begin{array}{l}\text { Sarcolemmal } \\
\text { membrane in } \mathrm{T} \text { - } \\
\text { tubule }\end{array}$ & $\begin{array}{l}\text { Calcium entry into cytosol in } \\
\text { response to sarcolemmal } \\
\text { depolarization }\end{array}$ \\
\hline Dynamin-related protein 1 & Drp1 & Cytoplasm & Promotion of mitochondrial \\
\hline
\end{tabular}




\begin{tabular}{|c|c|c|c|}
\hline & & & fusion \\
\hline Endonuclease G & EndoG & $\begin{array}{l}\text { Mitochondria } \\
\text { (unactivated) } \\
\text { Nucleus (activated) }\end{array}$ & $\begin{array}{l}\text { Endonuclease activity during } \\
\text { apoptotic processus }\end{array}$ \\
\hline $\begin{array}{l}\text { eukaryotic translation } \\
\text { initiation Factor } 2 \alpha\end{array}$ & eiF2a & Cytoplasm & Inhibition of mRNA translation \\
\hline $\begin{array}{l}\text { Extracellular signal- } \\
\text { Regulated Kinase }\end{array}$ & ERK & Cytoplasm & Kinase \\
\hline Fission 1 & Fis1 & $\begin{array}{l}\text { Outer } \\
\text { mitochondrial } \\
\text { membrane }\end{array}$ & $\begin{array}{l}\text { Promotion of mitochondrial } \\
\text { fusion }\end{array}$ \\
\hline Forkhead box & FoxO & Cytoplasm & Protein degradation control \\
\hline $\begin{array}{l}\text { Glucose-related proteins } 78, \\
94 \& 170\end{array}$ & $\begin{array}{l}\text { Grp78, } 94 \& \\
170\end{array}$ & $\begin{array}{l}\text { Endoplasmic } \\
\text { reticulum }\end{array}$ & Protein folding \\
\hline Glucose Transporter 4 & GLUT4 & $\begin{array}{l}\text { Sarcolemmal } \\
\text { membrane }\end{array}$ & $\begin{array}{l}\text { Glucose entry into skeletal } \\
\text { muscle }\end{array}$ \\
\hline Glycogen Synthase & GS & Cytoplasm & Glycogen Synthesis \\
\hline $\begin{array}{l}\text { Glycogen Synthase Kinase } \\
3 \beta\end{array}$ & GSK3 $\beta$ & Cytoplasm & Repression of GS activity \\
\hline Heat shock protein $72-\mathrm{kDa}$ & Hsp72 & Cytoplasm & $\begin{array}{l}\text { Promotion of mitochondrial } \\
\text { degradation }\end{array}$ \\
\hline $\begin{array}{l}\text { human 8-OxoGuanine DNA } \\
\text { N-glycosylase } 1\end{array}$ & hOGG1 & Mitochondria & Mitochondrial DNA repair \\
\hline Inositol-Requiring Enzyme 1 & IRE1 & $\begin{array}{l}\text { Endoplasmic } \\
\text { reticulum } \\
\text { membrane }\end{array}$ & ER stress sensor \\
\hline Insulin Rreceptor & IR & $\begin{array}{l}\text { Sarcolemmal } \\
\text { membrane }\end{array}$ & $\begin{array}{l}\text { Binding insulin and } \\
\text { phosphorylation of IRS1 }\end{array}$ \\
\hline Insulin Receptor Substrates & IRS & Cytoplasm & Recruitment of $\mathrm{PI} 3 \mathrm{~K}$ \\
\hline KetoSphinganine Reductase & KSR & $\begin{array}{l}\text { Endoplasmic } \\
\text { reticulum }\end{array}$ & Sphinganine synthesis \\
\hline $\begin{array}{l}\text { mammalian Target Of } \\
\text { Rapamycin }\end{array}$ & mTOR & Cytoplasm & $\begin{array}{l}\text { Phosphorylation of Ser473 of } \\
\text { Akt } \\
\text { Protein synthesis control }\end{array}$ \\
\hline $\begin{array}{l}\text { Manganese-dependent } \\
\text { SuperOxide Dismutase }\end{array}$ & MnSOD & $\begin{array}{l}\text { Mitochondrial } \\
\text { matrix }\end{array}$ & Superoxide detoxification \\
\hline $\begin{array}{l}\text { microtubule-associated } \\
\text { protein-1 Light Chain-3 }\end{array}$ & LC3 & Cytoplasm & Promotion of autophagy \\
\hline Mitofusin 1 & Mfn1 & Outer & Promotion of outer \\
\hline
\end{tabular}




\begin{tabular}{|c|c|c|c|}
\hline & & $\begin{array}{l}\text { mitochondrial } \\
\text { membrane }\end{array}$ & $\begin{array}{l}\text { mitochondrial membrane } \\
\text { fusion }\end{array}$ \\
\hline Mitofusin 2 & Mfn2 & $\begin{array}{l}\text { Outer } \\
\text { mitochondrial } \\
\text { membrane \& ER } \\
\text { membrane }\end{array}$ & $\begin{array}{l}\text { Promotion of outer } \\
\text { mitochondrial membrane } \\
\text { fusion } \\
\text { Promotion of mitochondrial } \\
\text { degradation }\end{array}$ \\
\hline Nuclear Factor к B & NFKB & Cytoplasm & $\begin{array}{l}\text { Pro-inflammatory transcription } \\
\text { factor }\end{array}$ \\
\hline Optic atrophy 1 & Opa1 & $\begin{array}{l}\text { Inner mitochondrial } \\
\text { membrane }\end{array}$ & $\begin{array}{l}\text { Promotion of inner } \\
\text { mitochondrial membrane } \\
\text { fusion }\end{array}$ \\
\hline parkin2 & & Cytoplasm & Promotion of mitophagy \\
\hline $\begin{array}{l}\text { Peroxisome Proliferator- } \\
\text { activated receptor (PPAR) y } \\
\text { Coactivator-1- } \alpha \text { \& } \beta\end{array}$ & PGC-1 $\alpha \& \beta$ & Cytoplasm & $\begin{array}{l}\text { Promotion of mitochondrial } \\
\text { biogenesis }\end{array}$ \\
\hline $\begin{array}{l}\text { PTEN induced putative } \\
\text { kinase } 1\end{array}$ & Pink1 & Cytoplasm & Promotion of mitophagy \\
\hline $\begin{array}{l}\text { Phosphatidylinositol-3- } \\
\text { Kinase }\end{array}$ & $\mathrm{PI} 3 \mathrm{~K}$ & Cytoplasm & Phosphorylation of PIP2 \\
\hline $\begin{array}{l}\text { Phosphatidylinositol } \\
\text { biPhosphate }\end{array}$ & PIP2 & $\begin{array}{l}\text { Sarcolemmal } \\
\text { membrane }\end{array}$ & Target of PI3K \\
\hline $\begin{array}{l}\text { Phosphatidylinositol } \\
\text { triPhosphate }\end{array}$ & PIP3 & $\begin{array}{l}\text { Sarcolemmal } \\
\text { membrane }\end{array}$ & $\begin{array}{l}\text { Recruitment of Akt at the } \\
\text { sarcolemmal membrane }\end{array}$ \\
\hline $\begin{array}{l}\text { Phosphoinositide-Dependent } \\
\text { Kinase-1 }\end{array}$ & PDK1 & $\begin{array}{l}\text { Sarcolemmal } \\
\text { membrane }\end{array}$ & $\begin{array}{l}\text { Phosphorylation of Thr308 of } \\
\text { Akt }\end{array}$ \\
\hline Protein Kinase C & PKC & Cytoplasm & Kinase \\
\hline $\begin{array}{l}\text { Protein kinase R-like ER } \\
\text { Kinase }\end{array}$ & PERK & $\begin{array}{l}\text { Endoplasmic } \\
\text { reticulum } \\
\text { membrane }\end{array}$ & ER stress sensor \\
\hline $\begin{array}{l}\text { Protein Tyrosine } \\
\text { Phosphatase 1B }\end{array}$ & PTP1B & $\begin{array}{l}\text { Endoplasmic } \\
\text { reticulum } \\
\text { membrane }\end{array}$ & $\begin{array}{l}\text { Targeting phosphorylated } \\
\text { residues of IR and IRS1 }\end{array}$ \\
\hline Ryanodine Receptor & RyR & $\begin{array}{l}\text { Endoplasmic } \\
\text { reticulum } \\
\text { membrane }\end{array}$ & $\begin{array}{l}\text { Release of ER calcium in } \\
\text { cytosol to allows muscular } \\
\text { contraction }\end{array}$ \\
\hline $\begin{array}{l}\text { Sarco/Endoplasmic } \\
\text { Reticulum Calcium-ATPase }\end{array}$ & SERCA & $\begin{array}{l}\text { Endoplasmic } \\
\text { reticulum } \\
\text { membrane }\end{array}$ & $\begin{array}{l}\text { Recapture of calcium into } \\
\text { sarcoplasmic reticulum }\end{array}$ \\
\hline Serine PalmitoylTransferase & SPT & $\begin{array}{l}\text { Endoplasmic } \\
\text { reticulum }\end{array}$ & 3-Ketosphinganine formation \\
\hline
\end{tabular}




\begin{tabular}{|l|l|l|l|}
\hline Site-1 and Site-2 proteases & SP1/SP2 & $\begin{array}{l}\text { Golgi apparatus } \\
\text { membrane }\end{array}$ & Cleavage of ATF6 \\
\hline Sirtuin 1 & SIRT1 & Cytoplasm & Deacetylation of PGC-1a \\
\hline $\begin{array}{l}\text { Skeletal muscle and Kidney- } \\
\text { enriched inositol } \\
\text { polyphosphate Phosphatase }\end{array}$ & SKIP & $\begin{array}{l}\text { Endoplasmic } \\
\text { reticulum }\end{array}$ & Phosphatase \\
\hline spliced X-box binding-1 & SXBP1 & Cytoplasm & $\begin{array}{l}\text { Activated transcription factor } \\
\text { of UPR signalling }\end{array}$ \\
\hline unspliced X-box binding-1 & uXBP1 & Cytoplasm & $\begin{array}{l}\text { Inactivated transcription factor } \\
\text { of UPR signalling }\end{array}$ \\
\hline
\end{tabular}

Table 2: Therapeutics aiming insulin sensitivity improvement and their consequences on skeletal muscle mitochondria and ER functions.

\begin{tabular}{|c|c|c|c|c|}
\hline Intervention & Procedure/treatment & Effects & Population & references \\
\hline \multirow[t]{3}{*}{$\begin{array}{l}\text { Calorie } \\
\text { restriction }\end{array}$} & $10 \%$ weight loss & $\begin{array}{l}\text { Reduction in succinate } \\
\text { dehydrogenase activity }\end{array}$ & $\begin{array}{l}\text { Overweight } \\
\text { to obese } \\
\text { adults }\end{array}$ & [122] \\
\hline & $\begin{array}{l}\text { Reduction of calorie } \\
\text { intake by } 25 \%\end{array}$ & $\begin{array}{l}\text { No changes in mitochondrial } \\
\text { content and ETC activity }\end{array}$ & $\begin{array}{l}\text { Overweight } \\
\text { to obese } \\
\text { adults }\end{array}$ & [124] \\
\hline & $\begin{array}{l}16 \text { weeks of calorie } \\
\text { restriction }\end{array}$ & $\begin{array}{l}\text { No effects on mitochondrial } \\
\text { function, ceramide levels or } \\
\mathrm{mtH}_{2} \mathrm{O}_{2} \text { production. }\end{array}$ & $\begin{array}{l}\text { Obese } \\
\text { subjects }\end{array}$ & [123] \\
\hline \multirow[t]{4}{*}{$\begin{array}{l}\text { Bariatric } \\
\text { surgery }\end{array}$} & $\begin{array}{l}\text { Roux-en-Y-Gastric } \\
\text { Bypass } \\
+/ \text { - exercise (2h/week, } \\
\text { for } 3 \text { months) }\end{array}$ & $\begin{array}{l}\text { RYGB: reduction in muscle } \\
\text { ceramide, better oxidative } \\
\text { phosphorylation } \\
\text { Exercise: Cardiolipin } \\
\text { remodelling, higher } \\
\text { mitochondrial respiratory } \\
\text { capacity }\end{array}$ & $\begin{array}{l}\text { Obese } \\
\text { subjects }\end{array}$ & [125] \\
\hline & $\begin{array}{l}\text { RYGB or sleeve } \\
\text { gastrectomy, } 12 \\
\text { months after surgery }\end{array}$ & $\begin{array}{l}\text { Trend to increased maximal } \\
\text { respiration }\end{array}$ & $\begin{array}{l}\text { Obese } \\
\text { subjects }\end{array}$ & [126] \\
\hline & $\begin{array}{l}\text { RYGB, } 3 \text { and } 12 \\
\text { months after surgery }\end{array}$ & $\begin{array}{l}\text { Increases in PGC-1 } \alpha \text { and } \\
\text { Mfn2 expression }\end{array}$ & $\begin{array}{l}\text { Obese } \\
\text { subjects }\end{array}$ & [127] \\
\hline & $\begin{array}{l}\text { Bilio-pancreatic } \\
\text { diversion, 2-year } \\
\text { follow-up }\end{array}$ & $\begin{array}{l}\text { Increases in Mfn2 mRNA and } \\
\text { glucose oxidation }\end{array}$ & $\begin{array}{l}\text { Obese } \\
\text { subjects }\end{array}$ & [128] \\
\hline
\end{tabular}




\begin{tabular}{|c|c|c|c|c|}
\hline \multirow[t]{6}{*}{ Exercise } & $\begin{array}{l}60 \mathrm{~min} / \text { day, } 5 \text { days/wk, } \\
\text { total duration } 12 \text { weeks }\end{array}$ & $\begin{array}{l}\text { Decrease in Drp1-Ser616 } \\
\text { Trend to increased Mfn1/2 }\end{array}$ & $\begin{array}{l}\text { Obese } \\
\text { subjects }\end{array}$ & [130] \\
\hline & $\begin{array}{l}60 \mathrm{~min} / \text { day, } 5 \text { days/wk, } \\
\text { total duration } 12 \text { weeks }\end{array}$ & $\begin{array}{l}\text { Better mitochondrial } \\
\text { efficiency } \\
\text { Reduced mitochondrial } \mathrm{H}_{2} \mathrm{O}_{2} \\
\text { emission }\end{array}$ & $\begin{array}{l}\text { Obese } \\
\text { women }\end{array}$ & [153] \\
\hline & $\begin{array}{l}5 \mathrm{~h} / \text { week of } \\
\text { unsupervised Nordic } \\
\text { walking with poles, } 4 \\
\text { months }\end{array}$ & $\begin{array}{l}\text { Increases in mitochondrial } \\
\text { components in patients that } \\
\text { become normoglucose } \\
\text { tolerant }\end{array}$ & $\begin{array}{l}\text { Overweight } \\
\text { with } \\
\text { impaired } \\
\text { glucose } \\
\text { tolerance }\end{array}$ & [154] \\
\hline & $\begin{array}{l}\text { Resistance training, } \\
\text { three times } 45 \\
\text { min/week, } 9 \text { months }\end{array}$ & $\begin{array}{l}\text { Increases in mtDNA, } \\
\text { mitochondrial components } \\
\text { and fatty acid oxidation }\end{array}$ & $\begin{array}{l}\text { Type } 2 \\
\text { diabetes } \\
\text { patients }\end{array}$ & [155] \\
\hline & $\begin{array}{l}10 \text { weeks of cycling, } 5 \\
\text { sessions of } \\
30 \mathrm{~min} / \text { week }\end{array}$ & $\begin{array}{l}\text { Increased mitochondrial } \\
\text { respiration in both groups }\end{array}$ & $\begin{array}{l}\text { Obese and } \\
\text { type } 2 \\
\text { diabetic } \\
\text { patients }\end{array}$ & [156] \\
\hline & $\begin{array}{l}\text { 12-week exercise } \\
\text { program ( } 2 \text { aerobic } \\
\text { sessions, } 1 \text { resistance } \\
\text { session per week) }\end{array}$ & $\begin{array}{l}\text { Increased mitochondrial } \\
\text { respiration and density and } \\
\text { higher metabolic flexibility }\end{array}$ & $\begin{array}{l}\text { Type } 2 \\
\text { diabetic } \\
\text { subjects }\end{array}$ & [157] \\
\hline \multirow[t]{2}{*}{$\begin{array}{l}\text { Exercise + } \\
\text { nutritional } \\
\text { changes }\end{array}$} & $\begin{array}{l}\text { Diet-induced weight } \\
\text { loss (10\% BW over } 16 \\
\text { weeks) } \\
\text { Aerobic exercise } \\
\text { (45min/session, } 4-5 \\
\text { sessions/week, } 16 \\
\text { weeks) }\end{array}$ & $\begin{array}{l}\text { Both procedures: reductions } \\
\text { in DAG } \\
\text { Exercise: reduction in } \\
\text { ceramide levels } \\
\text { Reduction in SDH activity in } \\
\text { diet-induced } \\
\text { weight loss } \\
\text { Increase in SDH activity in } \\
\text { exercised group }\end{array}$ & $\begin{array}{l}\text { Overweight } \\
\text { to obese } \\
\text { adults }\end{array}$ & [122] \\
\hline & $\begin{array}{l}7 \% \text { weight loss in both } \\
\text { groups within } 16-20 \\
\text { weeks } \\
\text { diet plus exercise } \\
\text { group }\end{array}$ & $\begin{array}{l}\text { Diet only: reduction in } \\
\text { mitochondrial size, } \\
\text { Diet+exercise: higher } \\
\text { mitochondrial density, } \\
\text { cardiolipin content and NADH } \\
\text { oxidase activity }\end{array}$ & $\begin{array}{l}\text { Overweight } \\
\text { to obese } \\
\text { adults }\end{array}$ & [124] \\
\hline \multirow[t]{2}{*}{$\begin{array}{l}\text { Pharmacolog } \\
\text { ical } \\
\text { treatments }\end{array}$} & $\begin{array}{l}\text { Pioglitazone, } 45 \text { mg/d, } \\
6 \text { months }\end{array}$ & $\begin{array}{l}\text { Increased the } \\
\text { phosphorylation of AMPK } \\
\text { Increases in genes involved } \\
\text { in fatty acid oxidation and } \\
\text { mitochondrial function }\end{array}$ & $\begin{array}{l}\text { Type } 2 \\
\text { diabetic } \\
\text { subjects }\end{array}$ & [136] \\
\hline & $\begin{array}{l}\text { Muraglitazar, } 5 \mathrm{mg} / \mathrm{d} \text {, } \\
\text { or placebo for } 16 \\
\text { weeks }\end{array}$ & $\begin{array}{l}\text { Increases in AMPK, PGC-1a } \\
\text { and mitochondrial function } \\
\text { related genes }\end{array}$ & $\begin{array}{l}\text { Type } 2 \\
\text { diabetic } \\
\text { subjects }\end{array}$ & [135] \\
\hline
\end{tabular}




\begin{tabular}{|c|c|c|c|}
\hline $\begin{array}{l}\text { Rosiglitazone (twice } 4 \\
\text { mg per day) for } 8 \\
\text { weeks }\end{array}$ & $\begin{array}{l}\text { Increases in mRNA of PGC- } \\
1 \alpha \text { and PPAR } \beta / \delta \\
\text { Increases in mitochondrial } \\
\text { complex II activity }\end{array}$ & $\begin{array}{l}\text { Type } 2 \\
\text { diabetic } \\
\text { subjects }\end{array}$ & {$[28]$} \\
\hline $\begin{array}{l}\text { Rosiglitazone (up to } \\
\text { 4mg, twice a day) } 12 \\
\text { weeks }\end{array}$ & $\begin{array}{l}\text { Increases in mtDNA copy } \\
\text { number and OXPHOS } \\
\text { proteins along with increased } \\
\text { exercise capacity }\left(\mathrm{VO}_{2} \mathrm{max}\right)\end{array}$ & $\begin{array}{l}\text { Type } 2 \\
\text { diabetic } \\
\text { subjects }\end{array}$ & [158] \\
\hline $\begin{array}{l}\text { Rosiglitazone } 4 \mathrm{mg} \text {, } \\
\text { twice a day, } 8 \text { weeks }\end{array}$ & Increases in UCP3 & $\begin{array}{l}\text { Type } 2 \\
\text { diabetic } \\
\text { subjects }\end{array}$ & [132] \\
\hline $\begin{array}{l}\text { Rosiglitazone } 4 \mathrm{mg} \text {, } \\
\text { twice a day, } 8 \text { weeks }\end{array}$ & $\begin{array}{l}\text { No improvement in } \\
\text { mitochondrial function, no } \\
\text { changes in IMCL }\end{array}$ & $\begin{array}{l}\text { Type } 2 \\
\text { diabetic } \\
\text { subjects }\end{array}$ & [134] \\
\hline $\begin{array}{l}\text { Rosiglitazone }(4 \mathrm{mg} / \mathrm{d}) \text {, } \\
\text { pioglitazone }(30 \mathrm{mg} / \mathrm{d}) \text {, } \\
12 \mathrm{wks}\end{array}$ & $\begin{array}{l}\text { Rosiglitazone: reduction in } \\
\text { mitochondrial respiration } \\
\text { Pioglitazone: increases in } \\
\text { mitochondrial respiration and } \\
\text { complex II and III expression }\end{array}$ & $\begin{array}{l}\text { Overweight/ } \\
\text { obese } \\
\text { subjects }\end{array}$ & [133] \\
\hline $\begin{array}{l}150 \mathrm{mg} / \mathrm{d} \text { trans- } \\
\text { resveratrol, } 1 \text { month }\end{array}$ & $\begin{array}{l}\text { Increases in OXPHOS gene } \\
\text { expression } \\
\text { Higher AMPK activity, PGC- } \\
\text { 1a expression, mitochondrial } \\
\text { fatty acid utilization }\end{array}$ & $\begin{array}{l}\text { Healthy } \\
\text { male obese } \\
\text { volunteers }\end{array}$ & [138] \\
\hline $\begin{array}{l}150 \mathrm{mg} / \mathrm{d} \text { trans- } \\
\text { resveratrol, } 1 \text { month }\end{array}$ & $\begin{array}{l}\text { No improvement in peripheral } \\
\text { insulin sensitivity } \\
\text { Improved mitochondrial } \\
\text { function }\end{array}$ & $\begin{array}{l}\text { Type } 2 \\
\text { diabetic } \\
\text { subjects }\end{array}$ & [139] \\
\hline $\begin{array}{l}\text { TUDCA }(1,750 \mathrm{mg} / \mathrm{d} \text {, } \\
\text { orally), } 4 \text { weeks }\end{array}$ & $\begin{array}{l}\text { No changes in ER stress } \\
\text { markers }\end{array}$ & $\begin{array}{l}\text { Obese } \\
\text { subjects }\end{array}$ & [140] \\
\hline
\end{tabular}

\section{Acknowledgements}

AB is supported by a PhD scholarship from Lille University-Région Nord Pas-de-

Calais. The authors acknowledge funding supports from INSERM, Contrat Plan Etat Région (CPER), Région Nord Pas-de-Calais/FEDER, the European Genomic Institute for Diabetes (E.G.I.D., ANR-10-LABX-46) and the European Commission. Research Grant from the European Foundation for the Study of Diabetes (EFSD) (to $H D$ ), the Fondation Francophone pour la Recherche sur le Diabète (FFRD) (to HD), 
the European Commission (FP7) consortium Eurhythdia. BS is a member of the Institut Universitaire de France.

\section{References (up to 100 references...)}

[1] V.T. Samuel, G.I. Shulman, The pathogenesis of insulin resistance: integrating signaling pathways and substrate flux, J. Clin. Invest. 126 (2016) 12-22. doi:10.1172/JCI77812.

[2] D. Thiebaud, E. Jacot, R.A. DeFronzo, E. Maeder, E. Jequier, J.P. Felber, The effect of graded doses of insulin on total glucose uptake, glucose oxidation, and glucose storage in man, Diabetes. 31 (1982) 957-963.

[3] D.D. Sarbassov, D.A. Guertin, S.M. Ali, D.M. Sabatini, Phosphorylation and regulation of Akt/PKB by the rictor-mTOR complex, Science. 307 (2005) 1098-1101. doi:10.1126/science.1106148.

[4] D.R. Alessi, S.R. James, C.P. Downes, A.B. Holmes, P.R. Gaffney, C.B. Reese, P. Cohen, Characterization of a 3-phosphoinositide-dependent protein kinase which phosphorylates and activates protein kinase Balpha, Curr. Biol. CB. 7 (1997) 261-269.

[5] D.C. Chan, S.K. Gan, A.T.Y. Wong, P.H.R. Barrett, G.F. Watts, Association between skeletal muscle fat content and very-low-density lipoprotein-apolipoprotein B-100 transport in obesity: effect of weight loss, Diabetes Obes. Metab. 16 (2014) 994-1000. doi:10.1111/dom.12311.

[6] J.E. Schaffer, Lipotoxicity: when tissues overeat, Curr. Opin. Lipidol. 14 (2003) 281287. doi:10.1097/01.mol.0000073508.41685.7f.

[7] B.T. Levine, A.B. Levine, Metabolic Syndrome and Cardiovascular Disease, 2nd edition, Wiley-Blackwell, 2006.

[8] J. Rieusset, Contribution of mitochondria and endoplasmic reticulum dysfunction in insulin resistance: Distinct or interrelated roles?, Diabetes Metab. 41 (2015) 358-368. doi:10.1016/j.diabet.2015.02.006.

[9] G.M. Kowalski, D.P. De Souza, M.L. Burch, S. Hamley, J. Kloehn, A. Selathurai, D. Tull, S. O'Callaghan, M.J. McConville, C.R. Bruce, Application of dynamic metabolomics to examine in vivo skeletal muscle glucose metabolism in the chronically high-fat fed mouse, Biochem. Biophys. Res. Commun. 462 (2015) 27-32. doi:10.1016/j.bbrc.2015.04.096. [10] N. Tardif, J. Salles, C. Guillet, J. Tordjman, S. Reggio, J.-F. Landrier, C. Giraudet, V. Patrac, J. Bertrand-Michel, C. Migne, M.-L. Collin, J.-M. Chardigny, Y. Boirie, S. Walrand, Muscle ectopic fat deposition contributes to anabolic resistance in obese sarcopenic old rats through eIF2 $\alpha$ activation, Aging Cell. 13 (2014) 1001-1011. doi:10.1111/acel.12263. [11] E. Chanseaume, C. Malpuech-Brugère, V. Patrac, G. Bielicki, P. Rousset, K. Couturier, J. Salles, J.-P. Renou, Y. Boirie, B. Morio, Diets high in sugar, fat, and energy induce muscle type-specific adaptations in mitochondrial functions in rats, J. Nutr. 136 (2006) 2194-2200. 
[12] D. Laurent, L. Didier, B. Yerby, B. Yerby, R. Deacon, J. Gao, Diet-induced modulation of mitochondrial activity in rat muscle, Am. J. Physiol. Endocrinol. Metab. 293 (2007) E1169-1177. doi:10.1152/ajpendo.00263.2007.

[13] S. Timmers, M. Nabben, M. Bosma, B. van Bree, E. Lenaers, D. van Beurden, G. Schaart, M.S. Westerterp-Plantenga, W. Langhans, M.K.C. Hesselink, V.B. SchrauwenHinderling, P. Schrauwen, Augmenting muscle diacylglycerol and triacylglycerol content by blocking fatty acid oxidation does not impede insulin sensitivity, Proc. Natl. Acad. Sci. U. S. A. 109 (2012) 11711-11716. doi:10.1073/pnas.1206868109.

[14] T. Kim, L. He, M.S. Johnson, Y. Li, L. Zeng, Y. Ding, Q. Long, J.F. Moore, J.D. Sharer, T.R. Nagy, M.E. Young, P.A. Wood, Q. Yang, Carnitine Palmitoyltransferase 1b Deficiency Protects Mice from Diet-Induced Insulin Resistance, J. Diabetes Metab. 5 (2014) 361. doi:10.4172/2155-6156.1000361.

[15] R.L. Dobbins, L.S. Szczepaniak, B. Bentley, V. Esser, J. Myhill, J.D. McGarry, Prolonged inhibition of muscle carnitine palmitoyltransferase-1 promotes intramyocellular lipid accumulation and insulin resistance in rats, Diabetes. 50 (2001) 123-130.

[16] T. Kim, J.F. Moore, J.D. Sharer, K. Yang, P.A. Wood, Q. Yang, Carnitine Palmitoyltransferase 1b Deficient Mice Develop Severe Insulin Resistance After Prolonged High Fat Diet Feeding, J. Diabetes Metab. 5 (2014). doi:10.4172/2155-6156.1000401.

[17] E.J. Anderson, M.E. Lustig, K.E. Boyle, T.L. Woodlief, D.A. Kane, C.-T. Lin, J.W. Price, L. Kang, P.S. Rabinovitch, H.H. Szeto, J.A. Houmard, R.N. Cortright, D.H.

Wasserman, P.D. Neufer, Mitochondrial H2O2 emission and cellular redox state link excess fat intake to insulin resistance in both rodents and humans, J. Clin. Invest. 119 (2009) 573581. doi:10.1172/JCI37048.

[18] M.J. Boden, A.E. Brandon, J.D. Tid-Ang, E. Preston, D. Wilks, E. Stuart, M.E. Cleasby, N. Turner, G.J. Cooney, E.W. Kraegen, Overexpression of manganese superoxide dismutase ameliorates high-fat diet-induced insulin resistance in rat skeletal muscle, Am. J. Physiol. Endocrinol. Metab. 303 (2012) E798-805. doi:10.1152/ajpendo.00577.2011.

[19] C. Bonnard, A. Durand, S. Peyrol, E. Chanseaume, M.-A. Chauvin, B. Morio, H. Vidal, J. Rieusset, Mitochondrial dysfunction results from oxidative stress in the skeletal muscle of diet-induced insulin-resistant mice, J. Clin. Invest. 118 (2008) 789-800. doi:10.1172/JCI32601.

[20] S. Boudina, S. Sena, C. Sloan, A. Tebbi, Y.H. Han, B.T. O’Neill, R.C. Cooksey, D. Jones, W.L. Holland, D.A. McClain, E.D. Abel, Early mitochondrial adaptations in skeletal muscle to diet-induced obesity are strain dependent and determine oxidative stress and energy expenditure but not insulin sensitivity, Endocrinology. 153 (2012) 2677-2688.

doi:10.1210/en.2011-2147.

[21] S. Paglialunga, B. van Bree, M. Bosma, M.P. Valdecantos, E. Amengual-Cladera, J.A. Jörgensen, D. van Beurden, G.J.M. den Hartog, D.M. Ouwens, J.J. Briedé, P. Schrauwen, J. Hoeks, Targeting of mitochondrial reactive oxygen species production does not avert lipidinduced insulin resistance in muscle tissue from mice, Diabetologia. 55 (2012) 2759-2768. doi:10.1007/s00125-012-2626-X.

[22] C.R. Hancock, D.-H. Han, M. Chen, S. Terada, T. Yasuda, D.C. Wright, J.O. Holloszy, High-fat diets cause insulin resistance despite an increase in muscle mitochondria, Proc. Natl. Acad. Sci. U. S. A. 105 (2008) 7815-7820. doi:10.1073/pnas.0802057105. [23] N.M.A. van den Broek, J. Ciapaite, H.M.M.L. De Feyter, S.M. Houten, R.J.A. Wanders, J. a. L. Jeneson, K. Nicolay, J.J. Prompers, Increased mitochondrial content rescues in vivo muscle oxidative capacity in long-term high-fat-diet-fed rats, FASEB J. Off. Publ. Fed. Am. Soc. Exp. Biol. 24 (2010) 1354-1364. doi:10.1096/fj.09-143842. 
[24] T.R. Koves, P. Li, J. An, T. Akimoto, D. Slentz, O. Ilkayeva, G.L. Dohm, Z. Yan, C.B. Newgard, D.M. Muoio, Peroxisome proliferator-activated receptor-gamma co-activator 1alpha-mediated metabolic remodeling of skeletal myocytes mimics exercise training and reverses lipid-induced mitochondrial inefficiency, J. Biol. Chem. 280 (2005) 33588-33598. doi:10.1074/jbc.M507621200.

[25] L.M. Sparks, H. Xie, R.A. Koza, R. Mynatt, M.W. Hulver, G.A. Bray, S.R. Smith, A high-fat diet coordinately downregulates genes required for mitochondrial oxidative phosphorylation in skeletal muscle, Diabetes. 54 (2005) 1926-1933.

[26] A. Hammarstedt, P.-A. Jansson, C. Wesslau, X. Yang, U. Smith, Reduced expression of PGC-1 and insulin-signaling molecules in adipose tissue is associated with insulin resistance, Biochem. Biophys. Res. Commun. 301 (2003) 578-582.

[27] M.E. Patti, A.J. Butte, S. Crunkhorn, K. Cusi, R. Berria, S. Kashyap, Y. Miyazaki, I. Kohane, M. Costello, R. Saccone, E.J. Landaker, A.B. Goldfine, E. Mun, R. DeFronzo, J. Finlayson, C.R. Kahn, L.J. Mandarino, Coordinated reduction of genes of oxidative metabolism in humans with insulin resistance and diabetes: Potential role of PGC1 and NRF1, Proc. Natl. Acad. Sci. U. S. A. 100 (2003) 8466-8471. doi:10.1073/pnas.1032913100.

[28] M. Mensink, M.K.C. Hesselink, A.P. Russell, G. Schaart, J.-P. Sels, P. Schrauwen, Improved skeletal muscle oxidative enzyme activity and restoration of PGC-1 alpha and PPAR beta/delta gene expression upon rosiglitazone treatment in obese patients with type 2 diabetes mellitus, Int. J. Obes. 2005. 31 (2007) 1302-1310. doi:10.1038/sj.ijo.0803567. [29] A. Sriwijitkamol, D.K. Coletta, E. Wajcberg, G.B. Balbontin, S.M. Reyna, J. Barrientes, P.A. Eagan, C.P. Jenkinson, E. Cersosimo, R.A. DeFronzo, K. Sakamoto, N. Musi, Effect of acute exercise on AMPK signaling in skeletal muscle of subjects with type 2 diabetes: a time-course and dose-response study, Diabetes. 56 (2007) 836-848.

doi:10.2337/db06-1119.

[30] Z. Haohao, Q. Guijun, Z. Juan, K. Wen, C. Lulu, Resveratrol improves high-fat diet induced insulin resistance by rebalancing subsarcolemmal mitochondrial oxidation and antioxidantion, J. Physiol. Biochem. 71 (2015) 121-131. doi:10.1007/s13105-015-0392-1. [31] J.C. Milne, P.D. Lambert, S. Schenk, D.P. Carney, J.J. Smith, D.J. Gagne, L. Jin, O. Boss, R.B. Perni, C.B. Vu, J.E. Bemis, R. Xie, J.S. Disch, P.Y. Ng, J.J. Nunes, A.V. Lynch, H. Yang, H. Galonek, K. Israelian, W. Choy, A. Iffland, S. Lavu, O. Medvedik, D.A. Sinclair, J.M. Olefsky, M.R. Jirousek, P.J. Elliott, C.H. Westphal, Small molecule activators of SIRT1 as therapeutics for the treatment of type 2 diabetes, Nature. 450 (2007) 712-716. doi:10.1038/nature06261.

[32] C.R. Benton, J.G. Nickerson, J. Lally, X.-X. Han, G.P. Holloway, J.F.C. Glatz, J.J.F.P. Luiken, T.E. Graham, J.J. Heikkila, A. Bonen, Modest PGC-1alpha overexpression in muscle in vivo is sufficient to increase insulin sensitivity and palmitate oxidation in subsarcolemmal, not intermyofibrillar, mitochondria, J. Biol. Chem. 283 (2008) 4228-4240. doi:10.1074/jbc.M704332200.

[33] C.R. Benton, G.P. Holloway, X.-X. Han, Y. Yoshida, L.A. Snook, J. Lally, J.F.C. Glatz, J.J.F.P. Luiken, A. Chabowski, A. Bonen, Increased levels of peroxisome proliferatoractivated receptor gamma, coactivator 1 alpha (PGC-1alpha) improve lipid utilisation, insulin signalling and glucose transport in skeletal muscle of lean and insulin-resistant obese Zucker rats, Diabetologia. 53 (2010) 2008-2019. doi:10.1007/s00125-010-1773-1.

[34] P. Mishra, D.C. Chan, Metabolic regulation of mitochondrial dynamics, J. Cell Biol. 212 (2016) 379-387. doi:10.1083/jcb.201511036. 
[35] R. Liu, P. Jin, L. Yu, null LiqunYu, Y. Wang, L. Han, T. Shi, X. Li, Impaired mitochondrial dynamics and bioenergetics in diabetic skeletal muscle, PloS One. 9 (2014) e92810. doi:10.1371/journal.pone.0092810.

[36] D. Bach, S. Pich, F.X. Soriano, N. Vega, B. Baumgartner, J. Oriola, J.R. Daugaard, J. Lloberas, M. Camps, J.R. Zierath, R. Rabasa-Lhoret, H. Wallberg-Henriksson, M. Laville, M. Palacín, H. Vidal, F. Rivera, M. Brand, A. Zorzano, Mitofusin-2 determines mitochondrial network architecture and mitochondrial metabolism. A novel regulatory mechanism altered in obesity, J. Biol. Chem. 278 (2003) 17190-17197. doi:10.1074/jbc.M212754200.

[37] D. Sebastián, M.I. Hernández-Alvarez, J. Segalés, E. Sorianello, J.P. Muñoz, D. Sala, A. Waget, M. Liesa, J.C. Paz, P. Gopalacharyulu, M. Orešič, S. Pich, R. Burcelin, M. Palacín, A. Zorzano, Mitofusin 2 (Mfn2) links mitochondrial and endoplasmic reticulum function with insulin signaling and is essential for normal glucose homeostasis, Proc. Natl. Acad. Sci. U. S. A. 109 (2012) 5523-5528. doi:10.1073/pnas.1108220109.

[38] D. Kong, G. Song, C. Wang, H. Ma, L. Ren, Q. Nie, X. Zhang, K. Gan, Overexpression of mitofusin 2 improves translocation of glucose transporter 4 in skeletal muscle of high- fat diet- fed rats through AMP- activated protein kinase signaling, Mol. Med. Rep. 8 (2013) 205-210. doi:10.3892/mmr.2013.1457.

[39] X. Zhang, C. Wang, G. Song, K. Gan, D. Kong, Q. Nie, L. Ren, Mitofusion-2mediated alleviation of insulin resistance in rats through reduction in lipid intermediate accumulation in skeletal muscle, J. Biomed. Sci. 20 (2013) 45. doi:10.1186/1423-0127-20-45. [40] G.-Q. Chen, W.-J. Lian, G.-M. Wang, S. Wang, Y.-Q. Yang, Z.-W. Zhao, Altered microRNA expression in skeletal muscle results from high-fat diet-induced insulin resistance in mice, Mol. Med. Rep. 5 (2012) 1362-1368. doi:10.3892/mmr.2012.824.

[41] I.J. Gallagher, C. Scheele, P. Keller, A.R. Nielsen, J. Remenyi, C.P. Fischer, K. Roder, J. Babraj, C. Wahlestedt, G. Hutvagner, B.K. Pedersen, J.A. Timmons, Integration of microRNA changes in vivo identifies novel molecular features of muscle insulin resistance in type 2 diabetes, Genome Med. 2 (2010) 9. doi:10.1186/gm130.

[42] Y. Zhang, L. Yang, Y.-F. Gao, Z.-M. Fan, X.-Y. Cai, M.-Y. Liu, X.-R. Guo, C.-L. Gao, Z.-K. Xia, MicroRNA-106b induces mitochondrial dysfunction and insulin resistance in C2C12 myotubes by targeting mitofusin-2, Mol. Cell. Endocrinol. 381 (2013) 230-240. doi:10.1016/j.mce.2013.08.004.

[43] D. Bach, D. Naon, S. Pich, F.X. Soriano, N. Vega, J. Rieusset, M. Laville, C. Guillet, Y. Boirie, H. Wallberg-Henriksson, M. Manco, M. Calvani, M. Castagneto, M. Palacín, G. Mingrone, J.R. Zierath, H. Vidal, A. Zorzano, Expression of Mfn2, the Charcot-Marie-Tooth neuropathy type 2A gene, in human skeletal muscle: effects of type 2 diabetes, obesity, weight loss, and the regulatory role of tumor necrosis factor alpha and interleukin-6, Diabetes. 54 (2005) 2685-2693.

[44] H.-F. Jheng, P.-J. Tsai, S.-M. Guo, L.-H. Kuo, C.-S. Chang, I.-J. Su, C.-R. Chang, Y.$\mathrm{S}$. Tsai, Mitochondrial fission contributes to mitochondrial dysfunction and insulin resistance in skeletal muscle, Mol. Cell. Biol. 32 (2012) 309-319. doi:10.1128/MCB.05603-11.

[45] D.J. Klionsky, et al., Guidelines for the use and interpretation of assays for monitoring autophagy (3rd edition), Autophagy. 12 (2016) 1-222. doi:10.1080/15548627.2015.1100356. [46] J.J. Lemasters, Variants of mitochondrial autophagy: Types 1 and 2 mitophagy and micromitophagy (Type 3), Redox Biol. 2 (2014) 749-754. doi:10.1016/j.redox.2014.06.004. [47] B.G. Drew, V. Ribas, J.A. Le, D.C. Henstridge, J. Phun, Z. Zhou, T. Soleymani, P. Daraei, D. Sitz, L. Vergnes, J. Wanagat, K. Reue, M.A. Febbraio, A.L. Hevener, HSP72 is a mitochondrial stress sensor critical for Parkin action, oxidative metabolism, and insulin sensitivity in skeletal muscle, Diabetes. 63 (2014) 1488-1505. doi:10.2337/db13-0665. 
[48] D.C. Henstridge, C.R. Bruce, B.G. Drew, K. Tory, A. Kolonics, E. Estevez, J. Chung, N. Watson, T. Gardner, R.S. Lee-Young, T. Connor, M.J. Watt, K. Carpenter, M. Hargreaves, S.L. McGee, A.L. Hevener, M.A. Febbraio, Activating HSP72 in rodent skeletal muscle increases mitochondrial number and oxidative capacity and decreases insulin resistance, Diabetes. 63 (2014) 1881-1894. doi:10.2337/db13-0967.

[49] R. Kruse, B.F. Vind, S.J. Petersson, J.M. Kristensen, K. Højlund, Markers of autophagy are adapted to hyperglycaemia in skeletal muscle in type 2 diabetes, Diabetologia. 58 (2015) 2087-2095. doi:10.1007/s00125-015-3654-0.

[50] C.R. Bruce, A.L. Carey, J.A. Hawley, M.A. Febbraio, Intramuscular heat shock protein 72 and heme oxygenase- 1 mRNA are reduced in patients with type 2 diabetes: evidence that insulin resistance is associated with a disturbed antioxidant defense mechanism, Diabetes. 52 (2003) 2338-2345.

[51] H. Alemán-Mateo, M.T. López Teros, F.A. Ramírez, H. Astiazarán-García, Association between insulin resistance and low relative appendicular skeletal muscle mass: evidence from a cohort study in community-dwelling older men and women participants, J. Gerontol. A. Biol. Sci. Med. Sci. 69 (2014) 871-877. doi:10.1093/gerona/glt193.

[52] S. Lee, Y. Kim, D.A. White, J.L. Kuk, S. Arslanian, Relationships between insulin sensitivity, skeletal muscle mass and muscle quality in obese adolescent boys, Eur. J. Clin. Nutr. 66 (2012) 1366-1368. doi:10.1038/ejen.2012.142.

[53] S.-S. Moon, Low skeletal muscle mass is associated with insulin resistance, diabetes, and metabolic syndrome in the Korean population: the Korea National Health and Nutrition Examination Survey (KNHANES) 2009-2010, Endocr. J. 61 (2014) 61-70.

[54] M. Sandri, L. Barberi, A.Y. Bijlsma, B. Blaauw, K.A. Dyar, G. Milan, C. Mammucari, C.G.M. Meskers, G. Pallafacchina, A. Paoli, D. Pion, M. Roceri, V. Romanello, A.L. Serrano, L. Toniolo, L. Larsson, A.B. Maier, P. Muñoz-Cánoves, A. Musarò, M. Pende, C. Reggiani, R. Rizzuto, S. Schiaffino, Signalling pathways regulating muscle mass in ageing skeletal muscle: the role of the IGF1-Akt-mTOR-FoxO pathway, Biogerontology. 14 (2013) 303-323. doi:10.1007/s10522-013-9432-9.

[55] C.G. Lee, E.J. Boyko, E.S. Strotmeyer, C.E. Lewis, P.M. Cawthon, A.R. Hoffman, S.A. Everson-Rose, E. Barrett-Connor, E.S. Orwoll, Osteoporotic Fractures in Men Study Research Group, Association between insulin resistance and lean mass loss and fat mass gain in older men without diabetes mellitus, J. Am. Geriatr. Soc. 59 (2011) 1217-1224.

doi:10.1111/j.1532-5415.2011.03472.x.

[56] S.W. Park, B.H. Goodpaster, J.S. Lee, L.H. Kuller, R. Boudreau, N. de Rekeneire, T.B. Harris, S. Kritchevsky, F.A. Tylavsky, M. Nevitt, Y. Cho, A.B. Newman, Health, Aging, and Body Composition Study, Excessive loss of skeletal muscle mass in older adults with type 2 diabetes, Diabetes Care. 32 (2009) 1993-1997. doi:10.2337/dc09-0264.

[57] P. Srikanthan, A.L. Hevener, A.S. Karlamangla, Sarcopenia exacerbates obesityassociated insulin resistance and dysglycemia: findings from the National Health and Nutrition Examination Survey III, PloS One. 5 (2010) e10805. doi:10.1371/journal.pone.0010805.

[58] G. Gouspillou, I. Bourdel-Marchasson, R. Rouland, G. Calmettes, M. Biran, V. Deschodt-Arsac, S. Miraux, E. Thiaudiere, P. Pasdois, D. Detaille, J.-M. Franconi, M. Babot, V. Trézéguet, L. Arsac, P. Diolez, Mitochondrial energetics is impaired in vivo in aged skeletal muscle, Aging Cell. 13 (2014) 39-48. doi:10.1111/acel.12147.

[59] I. Trounce, E. Byrne, S. Marzuki, Decline in skeletal muscle mitochondrial respiratory chain function: possible factor in ageing, Lancet Lond. Engl. 1 (1989) 637-639. 
[60] A.-M. Joseph, P.J. Adhihetty, T.W. Buford, S.E. Wohlgemuth, H.A. Lees, L.M.-D. Nguyen, J.M. Aranda, B.D. Sandesara, M. Pahor, T.M. Manini, E. Marzetti, C.

Leeuwenburgh, The impact of aging on mitochondrial function and biogenesis pathways in skeletal muscle of sedentary high- and low-functioning elderly individuals, Aging Cell. 11 (2012) 801-809. doi:10.1111/j.1474-9726.2012.00844.x.

[61] M. Sandri, J. Lin, C. Handschin, W. Yang, Z.P. Arany, S.H. Lecker, A.L. Goldberg, B.M. Spiegelman, PGC-1alpha protects skeletal muscle from atrophy by suppressing FoxO3 action and atrophy-specific gene transcription, Proc. Natl. Acad. Sci. U. S. A. 103 (2006) 16260-16265. doi:10.1073/pnas.0607795103.

[62] D. Sebastián, E. Sorianello, J. Segalés, A. Irazoki, V. Ruiz-Bonilla, D. Sala, E. Planet, A. Berenguer-Llergo, J.P. Muñoz, M. Sánchez-Feutrie, N. Plana, M.I. Hernández-Álvarez, A.L. Serrano, M. Palacín, A. Zorzano, Mfn2 deficiency links age-related sarcopenia and impaired autophagy to activation of an adaptive mitophagy pathway, EMBO J. 35 (2016) 1677-1693. doi:10.15252/embj.201593084.

[63] T. Touvier, C. De Palma, E. Rigamonti, A. Scagliola, E. Incerti, L. Mazelin, J.-L. Thomas, M. D’Antonio, L. Politi, L. Schaeffer, E. Clementi, S. Brunelli, Muscle-specific Drp1 overexpression impairs skeletal muscle growth via translational attenuation, Cell Death Dis. 6 (2015) e1663. doi:10.1038/cddis.2014.595.

[64] T. Varanita, M.E. Soriano, V. Romanello, T. Zaglia, R. Quintana-Cabrera, M. Semenzato, R. Menabò, V. Costa, G. Civiletto, P. Pesce, C. Viscomi, M. Zeviani, F. Di Lisa, M. Mongillo, M. Sandri, L. Scorrano, The OPA1-dependent mitochondrial cristae remodeling pathway controls atrophic, apoptotic, and ischemic tissue damage, Cell Metab. 21 (2015) 834-844. doi:10.1016/j.cmet.2015.05.007.

[65] V. Romanello, E. Guadagnin, L. Gomes, I. Roder, C. Sandri, Y. Petersen, G. Milan, E. Masiero, P. Del Piccolo, M. Foretz, L. Scorrano, R. Rudolf, M. Sandri, Mitochondrial fission and remodelling contributes to muscle atrophy, EMBO J. 29 (2010) 1774-1785. doi:10.1038/emboj.2010.60.

[66] A. Vasilaki, A. Mansouri, H. Van Remmen, J.H. van der Meulen, L. Larkin, A.G. Richardson, A. McArdle, J.A. Faulkner, M.J. Jackson, Free radical generation by skeletal muscle of adult and old mice: effect of contractile activity, Aging Cell. 5 (2006) 109-117. doi:10.1111/j.1474-9726.2006.00198.x.

[67] K. Min, A.J. Smuder, O.-S. Kwon, A.N. Kavazis, H.H. Szeto, S.K. Powers, Mitochondrial-targeted antioxidants protect skeletal muscle against immobilization-induced muscle atrophy, J. Appl. Physiol. Bethesda Md 1985. 111 (2011) 1459-1466.

doi:10.1152/japplphysiol.00591.2011.

[68] E.E. Talbert, A.J. Smuder, K. Min, O.S. Kwon, H.H. Szeto, S.K. Powers, Immobilization-induced activation of key proteolytic systems in skeletal muscles is prevented by a mitochondria-targeted antioxidant, J. Appl. Physiol. Bethesda Md 1985. 115 (2013) 529538. doi:10.1152/japplphysiol.00471.2013.

[69] G. Gouspillou, N. Sgarioto, S. Kapchinsky, F. Purves-Smith, B. Norris, C.H. Pion, S. Barbat-Artigas, F. Lemieux, T. Taivassalo, J.A. Morais, M. Aubertin-Leheudre, R.T. Hepple, Increased sensitivity to mitochondrial permeability transition and myonuclear translocation of endonuclease $\mathrm{G}$ in atrophied muscle of physically active older humans, FASEB J. Off. Publ. Fed. Am. Soc. Exp. Biol. 28 (2014) 1621-1633. doi:10.1096/fj.13-242750.

[70] R.T. Dirksen, Sarcoplasmic Reticulum-Mitochondrial "Through-Space" Coupling in Skeletal Muscle, Appl. Physiol. Nutr. Metab. Physiol. Appl. Nutr. Metab. 34 (2009) 389-395. doi:10.1139/h09-044. 
[71] C. Chalfant, M. Del Poeta, Sphingolipids as Signaling and Regulatory Molecules, first edition, 2010.

[72] K. Hirschberg, J. Rodger, A.H. Futerman, The long-chain sphingoid base of

sphingolipids is acylated at the cytosolic surface of the endoplasmic reticulum in rat liver,

Biochem. J. 290 ( Pt 3) (1993) 751-757.

[73] J.M. Adams, T. Pratipanawatr, R. Berria, E. Wang, R.A. DeFronzo, M.C. Sullards, L.J. Mandarino, Ceramide content is increased in skeletal muscle from obese insulin-resistant humans, Diabetes. 53 (2004) 25-31.

[74] C.R. Gault, L.M. Obeid, Y.A. Hannun, An overview of sphingolipid metabolism: from synthesis to breakdown, Adv. Exp. Med. Biol. 688 (2010) 1-23.

[75] J.A. Chavez, T.A. Knotts, L.-P. Wang, G. Li, R.T. Dobrowsky, G.L. Florant, S.A. Summers, A role for ceramide, but not diacylglycerol, in the antagonism of insulin signal transduction by saturated fatty acids, J. Biol. Chem. 278 (2003) 10297-10303.

doi:10.1074/jbc.M212307200.

[76] D.J. Powell, E. Hajduch, G. Kular, H.S. Hundal, Ceramide disables 3-

phosphoinositide binding to the pleckstrin homology domain of protein kinase B (PKB)/Akt by a PKCzeta-dependent mechanism, Mol. Cell. Biol. 23 (2003) 7794-7808.

[77] G. Frangioudakis, B. Diakanastasis, B.-Q.M. Liao, J.T. Saville, N.J. Hoffman, T.W. Mitchell, C. Schmitz-Peiffer, Ceramide accumulation in L6 skeletal muscle cells due to increased activity of ceramide synthase isoforms has opposing effects on insulin action to those caused by palmitate treatment, Diabetologia. 56 (2013) 2697-2701.

doi:10.1007/s00125-013-3035-5.

[78] G. Frangioudakis, J. Garrard, K. Raddatz, J.L. Nadler, T.W. Mitchell, C. SchmitzPeiffer, Saturated- and n-6 polyunsaturated-fat diets each induce ceramide accumulation in mouse skeletal muscle: reversal and improvement of glucose tolerance by lipid metabolism inhibitors, Endocrinology. 151 (2010) 4187-4196. doi:10.1210/en.2010-0250.

[79] J.R. Ussher, T.R. Koves, V.J.J. Cadete, L. Zhang, J.S. Jaswal, S.J. Swyrd, D.G. Lopaschuk, S.D. Proctor, W. Keung, D.M. Muoio, G.D. Lopaschuk, Inhibition of de novo ceramide synthesis reverses diet-induced insulin resistance and enhances whole-body oxygen consumption, Diabetes. 59 (2010) 2453-2464. doi:10.2337/db09-1293.

[80] A.B. Thrush, E. Harasim, A. Chabowski, R. Gulli, L. Stefanyk, D.J. Dyck, A single prior bout of exercise protects against palmitate-induced insulin resistance despite an increase in total ceramide content, Am. J. Physiol. Regul. Integr. Comp. Physiol. 300 (2011) R12001208. doi:10.1152/ajpregu.00091.2010.

[81] C. Hetz, The unfolded protein response: controlling cell fate decisions under ER stress and beyond, Nat. Rev. Mol. Cell Biol. 13 (2012) 89-102. doi:10.1038/nrm3270.

[82] C. Hetz, E. Chevet, S.A. Oakes, Proteostasis control by the unfolded protein response, Nat. Cell Biol. 17 (2015) 829-838. doi:10.1038/ncb3184.

[83] M. Wang, R.J. Kaufman, Protein misfolding in the endoplasmic reticulum as a conduit to human disease, Nature. 529 (2016) 326-335. doi:10.1038/nature17041.

[84] S.-L. Hwang, J.H. Yang, Y.-T. Jeong, Y.D. Kim, X. Li, Y. Lu, Y.-C. Chang, K.H.

Son, H.W. Chang, Tanshinone IIA improves endoplasmic reticulum stress-induced insulin resistance through AMP-activated protein kinase, Biochem. Biophys. Res. Commun. 430 (2013) 1246-1252. doi:10.1016/j.bbrc.2012.12.066.

[85] T. Ijuin, T. Hosooka, T. Takenawa, Phosphatidylinositol 3,4,5-Trisphosphate Phosphatase SKIP Links Endoplasmic Reticulum Stress in Skeletal Muscle to Insulin Resistance, Mol. Cell. Biol. 36 (2016) 108-118. doi:10.1128/MCB.00921-15. 
[86] H.-J. Koh, T. Toyoda, M.M. Didesch, M.-Y. Lee, M.W. Sleeman, R.N. Kulkarni, N. Musi, M.F. Hirshman, L.J. Goodyear, Tribbles 3 mediates endoplasmic reticulum stressinduced insulin resistance in skeletal muscle, Nat. Commun. 4 (2013) 1871.

doi:10.1038/ncomms2851.

[87] E.-K. Yoon, Y.-T. Jeong, X. Li, null Song-Cui, D.-C. Park, Y.-H. Kim, Y.D. Kim, H.W. Chang, S.-H. Lee, S.-L. Hwang, Glyceollin improves endoplasmic reticulum stressinduced insulin resistance through CaMKK-AMPK pathway in L6 myotubes, J. Nutr. Biochem. 24 (2013) 1053-1061. doi:10.1016/j.jnutbio.2012.08.003.

[88] J. Rieusset, M.-A. Chauvin, A. Durand, A. Bravard, F. Laugerette, M.-C. Michalski, $\mathrm{H}$. Vidal, Reduction of endoplasmic reticulum stress using chemical chaperones or Grp78 overexpression does not protect muscle cells from palmitate-induced insulin resistance, Biochem. Biophys. Res. Commun. 417 (2012) 439-445. doi:10.1016/j.bbrc.2011.11.135. [89] L. Salvadó, T. Coll, A.M. Gómez-Foix, E. Salmerón, E. Barroso, X. Palomer, M. Vázquez-Carrera, Oleate prevents saturated-fatty-acid-induced ER stress, inflammation and insulin resistance in skeletal muscle cells through an AMPK-dependent mechanism, Diabetologia. 56 (2013) 1372-1382. doi:10.1007/s00125-013-2867-3.

[90] L. Deldicque, L. Bertrand, A. Patton, M. Francaux, K. Baar, ER stress induces anabolic resistance in muscle cells through PKB-induced blockade of mTORC1, PloS One. 6 (2011) e20993. doi:10.1371/journal.pone.0020993.

[91] S.-L. Hwang, Y.-T. Jeong, X. Li, Y.D. Kim, Y. Lu, Y.-C. Chang, I.-K. Lee, H.W. Chang, Inhibitory cross-talk between the AMPK and ERK pathways mediates endoplasmic reticulum stress-induced insulin resistance in skeletal muscle, Br. J. Pharmacol. 169 (2013) 69-81. doi:10.1111/bph.12124.

[92] S.-L. Hwang, X. Li, J.-Y. Lee, H.W. Chang, Improved insulin sensitivity by rapamycin is associated with reduction of mTOR and S6K1 activities in L6 myotubes, Biochem. Biophys. Res. Commun. 418 (2012) 402-407. doi:10.1016/j.bbrc.2012.01.038. [93] E. Panzhinskiy, Y. Hua, B. Culver, J. Ren, S. Nair, Endoplasmic reticulum stress upregulates protein tyrosine phosphatase $1 \mathrm{~B}$ and impairs glucose uptake in cultured myotubes, Diabetologia. 56 (2013) 598-607. doi:10.1007/s00125-012-2782-z.

[94] L. Salvadó, E. Barroso, A.M. Gómez-Foix, X. Palomer, L. Michalik, W. Wahli, M. Vázquez-Carrera, PPAR $\beta / \delta$ prevents endoplasmic reticulum stress-associated inflammation and insulin resistance in skeletal muscle cells through an AMPK-dependent mechanism, Diabetologia. 57 (2014) 2126-2135. doi:10.1007/s00125-014-3331-8.

[95] F. Urano, X. Wang, A. Bertolotti, Y. Zhang, P. Chung, H.P. Harding, D. Ron, Coupling of stress in the ER to activation of JNK protein kinases by transmembrane protein kinase IRE1, Science. 287 (2000) 664-666.

[96] K. Müssig, H. Fiedler, H. Staiger, C. Weigert, R. Lehmann, E.D. Schleicher, H.-U. Häring, Insulin-induced stimulation of JNK and the PI 3-kinase/mTOR pathway leads to phosphorylation of serine 318 of IRS-1 in C2C12 myotubes, Biochem. Biophys. Res. Commun. 335 (2005) 819-825. doi:10.1016/j.bbrc.2005.07.154.

[97] T. Ijuin, N. Hatano, T. Hosooka, T. Takenawa, Regulation of insulin signaling in skeletal muscle by PIP3 phosphatase, SKIP, and endoplasmic reticulum molecular chaperone glucose-regulated protein 78, Biochim. Biophys. Acta. 1853 (2015) 3192-3201. doi:10.1016/j.bbamcr.2015.09.009.

[98] G.A. Raciti, C. Iadicicco, L. Ulianich, B.F. Vind, M. Gaster, F. Andreozzi, M. Longo, R. Teperino, P. Ungaro, B. Di Jeso, P. Formisano, F. Beguinot, C. Miele, Glucosamineinduced endoplasmic reticulum stress affects GLUT4 expression via activating transcription 
factor 6 in rat and human skeletal muscle cells, Diabetologia. 53 (2010) 955-965. doi:10.1007/s00125-010-1676-1.

[99] Y.-T. Jeong, Y.D. Kim, Y.-M. Jung, D.-C. Park, D.-S. Lee, S.-K. Ku, X. Li, Y. Lu, G.H. Chao, K.-J. Kim, J.-Y. Lee, M.-C. Baek, W. Kang, S.-L. Hwang, H.W. Chang, Low molecular weight fucoidan improves endoplasmic reticulum stress-reduced insulin sensitivity through AMP-activated protein kinase activation in L6 myotubes and restores lipid homeostasis in a mouse model of type 2 diabetes, Mol. Pharmacol. 84 (2013) 147-157. doi:10.1124/mol.113.085100.

[100] H.J. Kwak, H.-E. Choi, J. Jang, S.K. Park, Y.-A. Bae, H.G. Cheon, Bortezomib attenuates palmitic acid-induced ER stress, inflammation and insulin resistance in myotubes via AMPK dependent mechanism, Cell. Signal. 28 (2016) 788-797.

doi:10.1016/j.cellsig.2016.03.015.

[101] Z. Ouyang, W. Li, Q. Meng, Q. Zhang, X. Wang, A. Elgehama, X. Wu, Y. Shen, Y. Sun, X. Wu, Q. Xu, A natural compound jaceosidin ameliorates endoplasmic reticulum stress and insulin resistance via upregulation of SERCA2b, Biomed. Pharmacother. Biomedecine Pharmacother. 89 (2017) 1286-1296. doi:10.1016/j.biopha.2017.03.023.

[102] K.A. Kenner, E. Anyanwu, J.M. Olefsky, J. Kusari, Protein-tyrosine phosphatase 1B is a negative regulator of insulin- and insulin-like growth factor-I-stimulated signaling, $\mathrm{J}$. Biol. Chem. 271 (1996) 19810-19816.

[103] E. Panzhinskiy, J. Ren, S. Nair, Protein tyrosine phosphatase 1B and insulin resistance: role of endoplasmic reticulum stress/reactive oxygen species/nuclear factor kappa B axis, PloS One. 8 (2013) e77228. doi:10.1371/journal.pone.0077228.

[104] A. Marette, Y. Liu, G. Sweeney, Skeletal muscle glucose metabolism and inflammation in the development of the metabolic syndrome, Rev. Endocr. Metab. Disord. 15 (2014) 299-305. doi:10.1007/s11154-014-9296-6.

[105] V. Varma, A. Yao-Borengasser, N. Rasouli, G.T. Nolen, B. Phanavanh, T. Starks, C. Gurley, P. Simpson, R.E. McGehee, P.A. Kern, C.A. Peterson, Muscle inflammatory response and insulin resistance: synergistic interaction between macrophages and fatty acids leads to impaired insulin action, Am. J. Physiol. Endocrinol. Metab. 296 (2009) E1300-1310. doi:10.1152/ajpendo.90885.2008.

[106] L. Cortez, V. Sim, The therapeutic potential of chemical chaperones in protein folding diseases, Prion. 8 (2014).

[107] S. Liong, M. Lappas, Endoplasmic reticulum stress regulates inflammation and insulin resistance in skeletal muscle from pregnant women, Mol. Cell. Endocrinol. 425 (2016) 11-25. doi:10.1016/j.mce.2016.02.016.

[108] R. Hage Hassan, I. Hainault, J.-T. Vilquin, C. Samama, F. Lasnier, P. Ferré, F. Foufelle, E. Hajduch, Endoplasmic reticulum stress does not mediate palmitate-induced insulin resistance in mouse and human muscle cells, Diabetologia. 55 (2012) 204-214. doi:10.1007/s00125-011-2328-9.

[109] U. Ozcan, Q. Cao, E. Yilmaz, A.-H. Lee, N.N. Iwakoshi, E. Ozdelen, G. Tuncman, C. Görgün, L.H. Glimcher, G.S. Hotamisligil, Endoplasmic reticulum stress links obesity, insulin action, and type 2 diabetes, Science. 306 (2004) 457-461. doi:10.1126/science.1103160. [110] R. Ye, D.Y. Jung, J.Y. Jun, J. Li, S. Luo, H.J. Ko, J.K. Kim, A.S. Lee, Grp78 heterozygosity promotes adaptive unfolded protein response and attenuates diet-induced obesity and insulin resistance, Diabetes. 59 (2010) 6-16. doi:10.2337/db09-0755.

[111] U. Ozcan, E. Yilmaz, L. Ozcan, M. Furuhashi, E. Vaillancourt, R.O. Smith, C.Z. Görgün, G.S. Hotamisligil, Chemical chaperones reduce ER stress and restore glucose 
homeostasis in a mouse model of type 2 diabetes, Science. 313 (2006) 1137-1140.

doi:10.1126/science.1128294.

[112] K. Ozawa, M. Miyazaki, M. Matsuhisa, K. Takano, Y. Nakatani, M. Hatazaki, T. Tamatani, K. Yamagata, J.-I. Miyagawa, Y. Kitao, O. Hori, Y. Yamasaki, S. Ogawa, The endoplasmic reticulum chaperone improves insulin resistance in type 2 diabetes, Diabetes. 54 (2005) 657-663.

[113] S. Park, J. Choi, T. Nam, J. Ku, K. Jeong, Anti-diabetic effect of 3-hydroxy-2naphthoic acid, an endoplasmic reticulum stress-reducing chemical chaperone, Eur. J. Pharmacol. 779 (2016) 157-167. doi:10.1016/j.ejphar.2016.03.023.

[114] L. Deldicque, K. Van Proeyen, M. Francaux, P. Hespel, The unfolded protein response in human skeletal muscle is not involved in the onset of glucose tolerance impairment induced by a fat-rich diet, Eur. J. Appl. Physiol. 111 (2011) 1553-1558. doi:10.1007/s00421-0101783-1.

[115] T. Ogata, S. Machida, Y. Oishi, M. Higuchi, I. Muraoka, Differential cell death regulation between adult-unloaded and aged rat soleus muscle, Mech. Ageing Dev. 130 (2009) 328-336. doi:10.1016/j.mad.2009.02.001.

[116] Y. Kouroku, E. Fujita, I. Tanida, T. Ueno, A. Isoai, H. Kumagai, S. Ogawa, R.J. Kaufman, E. Kominami, T. Momoi, ER stress (PERK/eIF2alpha phosphorylation) mediates the polyglutamine-induced LC3 conversion, an essential step for autophagy formation, Cell Death Differ. 14 (2007) 230-239. doi:10.1038/sj.cdd.4401984.

[117] L.V. Yuzefovych, S.I. Musiyenko, G.L. Wilson, L.I. Rachek, Mitochondrial DNA damage and dysfunction, and oxidative stress are associated with endoplasmic reticulum stress, protein degradation and apoptosis in high fat diet-induced insulin resistance mice, PloS One. 8 (2013) e54059. doi:10.1371/journal.pone.0054059.

[118] C. Moorwood, E.R. Barton, Caspase-12 ablation preserves muscle function in the mdx mouse, Hum. Mol. Genet. 23 (2014) 5325-5341. doi:10.1093/hmg/ddu249.

[119] J. Du, X. Wang, C. Miereles, J.L. Bailey, R. Debigare, B. Zheng, S.R. Price, W.E. Mitch, Activation of caspase-3 is an initial step triggering accelerated muscle proteolysis in catabolic conditions, J. Clin. Invest. 113 (2004) 115-123. doi:10.1172/JCI18330.

[120] E.E. Dupont-Versteegden, B.A. Strotman, C.M. Gurley, D. Gaddy, M. Knox, J.D. Fluckey, C.A. Peterson, Nuclear translocation of EndoG at the initiation of disuse muscle atrophy and apoptosis is specific to myonuclei, Am. J. Physiol. Regul. Integr. Comp. Physiol. 291 (2006) R1730-1740. doi:10.1152/ajpregu.00176.2006.

[121] S.M. Turpin, G.I. Lancaster, I. Darby, M.A. Febbraio, M.J. Watt, Apoptosis in skeletal muscle myotubes is induced by ceramides and is positively related to insulin resistance, Am. J. Physiol. Endocrinol. Metab. 291 (2006) E1341-1350. doi:10.1152/ajpendo.00095.2006. [122] J.J. Dubé, F. Amati, F.G.S. Toledo, M. Stefanovic-Racic, A. Rossi, P. Coen, B.H. Goodpaster, Effects of weight loss and exercise on insulin resistance, and intramyocellular triacylglycerol, diacylglycerol and ceramide, Diabetologia. 54 (2011) 1147-1156. doi:10.1007/s00125-011-2065-0.

[123] M.L. Johnson, K. Distelmaier, I.R. Lanza, B.A. Irving, M.M. Robinson, A.R. Konopka, G.I. Shulman, K.S. Nair, Mechanism by Which Caloric Restriction Improves Insulin Sensitivity in Sedentary Obese Adults, Diabetes. 65 (2016) 74-84. doi:10.2337/db150675 .

[124] F.G.S. Toledo, E.V. Menshikova, K. Azuma, Z. Radiková, C.A. Kelley, V.B. Ritov, D.E. Kelley, Mitochondrial capacity in skeletal muscle is not stimulated by weight loss despite increases in insulin action and decreases in intramyocellular lipid content, Diabetes. 57 (2008) 987-994. doi:10.2337/db07-1429. 
[125] P.M. Coen, E.V. Menshikova, G. Distefano, D. Zheng, C.J. Tanner, R.A. Standley, N.L. Helbling, G.S. Dubis, V.B. Ritov, H. Xie, M.E. Desimone, S.R. Smith, M. StefanovicRacic, F.G.S. Toledo, J.A. Houmard, B.H. Goodpaster, Exercise and Weight Loss Improve Muscle Mitochondrial Respiration, Lipid Partitioning, and Insulin Sensitivity After Gastric Bypass Surgery, Diabetes. 64 (2015) 3737-3750. doi:10.2337/db15-0809.

[126] S. Nijhawan, W. Richards, M.F. O’Hea, J.P. Audia, D.F. Alvarez, Bariatric surgery rapidly improves mitochondrial respiration in morbidly obese patients, Surg. Endosc. 27 (2013) 4569-4573. doi:10.1007/s00464-013-3125-y.

[127] G. Gastaldi, A. Russell, A. Golay, J.-P. Giacobino, F. Habicht, V. Barthassat, P. Muzzin, E. Bobbioni-Harsch, Upregulation of peroxisome proliferator-activated receptor gamma coactivator gene (PGC1A) during weight loss is related to insulin sensitivity but not to energy expenditure, Diabetologia. 50 (2007) 2348-2355. doi:10.1007/s00125-007-0782-1. [128] G. Mingrone, M. Manco, M. Calvani, M. Castagneto, D. Naon, A. Zorzano, Could the low level of expression of the gene encoding skeletal muscle mitofusin-2 account for the metabolic inflexibility of obesity?, Diabetologia. 48 (2005) 2108-2114. doi:10.1007/s00125005-1918-9.

[129] M.K.C. Hesselink, V. Schrauwen-Hinderling, P. Schrauwen, Skeletal muscle mitochondria as a target to prevent or treat type 2 diabetes mellitus, Nat. Rev. Endocrinol. 12 (2016) 633-645. doi:10.1038/nrendo.2016.104.

[130] C.E. Fealy, A. Mulya, N. Lai, J.P. Kirwan, Exercise training decreases activation of the mitochondrial fission protein dynamin-related protein-1 in insulin-resistant human skeletal muscle, J. Appl. Physiol. Bethesda Md 1985. 117 (2014) 239-245.

doi:10.1152/japplphysiol.01064.2013.

[131] W. Wang, G. Karamanlidis, R. Tian, Novel targets for mitochondrial medicine, Sci. Transl. Med. 8 (2016) 326rv3. doi:10.1126/scitranslmed.aac7410.

[132] P. Schrauwen, M. Mensink, G. Schaart, E. Moonen-Kornips, J.-P. Sels, E.E. Blaak, A.P. Russell, M.K.C. Hesselink, Reduced skeletal muscle uncoupling protein-3 content in prediabetic subjects and type 2 diabetic patients: restoration by rosiglitazone treatment, $\mathrm{J}$. Clin. Endocrinol. Metab. 91 (2006) 1520-1525. doi:10.1210/jc.2005-1572.

[133] R. Rabøl, R. Boushel, T. Almdal, C.N. Hansen, T. Ploug, S.B. Haugaard, C. Prats, S. Madsbad, F. Dela, Opposite effects of pioglitazone and rosiglitazone on mitochondrial respiration in skeletal muscle of patients with type 2 diabetes, Diabetes Obes. Metab. 12 (2010) 806-814. doi:10.1111/j.1463-1326.2010.01237.x.

[134] V.B. Schrauwen-Hinderling, M. Mensink, M.K.C. Hesselink, J.-P. Sels, M.E. Kooi, P. Schrauwen, The insulin-sensitizing effect of rosiglitazone in type 2 diabetes mellitus patients does not require improved in vivo muscle mitochondrial function, J. Clin. Endocrinol. Metab. 93 (2008) 2917-2921. doi:10.1210/jc.2008-0267.

[135] D.K. Coletta, M. Fernandez, E. Cersosimo, A. Gastaldelli, N. Musi, R.A. DeFronzo, The effect of muraglitazar on adiponectin signalling, mitochondrial function and fat oxidation genes in human skeletal muscle in vivo, Diabet. Med. J. Br. Diabet. Assoc. 32 (2015) 657664. doi:10.1111/dme.12664.

[136] D.K. Coletta, A. Sriwijitkamol, E. Wajcberg, P. Tantiwong, M. Li, M. Prentki, M. Madiraju, C.P. Jenkinson, E. Cersosimo, N. Musi, R.A. Defronzo, Pioglitazone stimulates AMP-activated protein kinase signalling and increases the expression of genes involved in adiponectin signalling, mitochondrial function and fat oxidation in human skeletal muscle in vivo: a randomised trial, Diabetologia. 52 (2009) 723-732. doi:10.1007/s00125-008-1256-9. 
[137] S. Timmers, M.K.C. Hesselink, P. Schrauwen, Therapeutic potential of resveratrol in obesity and type 2 diabetes: new avenues for health benefits?, Ann. N. Y. Acad. Sci. 1290 (2013) 83-89. doi:10.1111/nyas.12185.

[138] S. Timmers, E. Konings, L. Bilet, R.H. Houtkooper, T. van de Weijer, G.H. Goossens, J. Hoeks, S. van der Krieken, D. Ryu, S. Kersten, E. Moonen-Kornips, M.K.C. Hesselink, I. Kunz, V.B. Schrauwen-Hinderling, E.E. Blaak, J. Auwerx, P. Schrauwen, Calorie restrictionlike effects of 30 days of resveratrol supplementation on energy metabolism and metabolic profile in obese humans, Cell Metab. 14 (2011) 612-622. doi:10.1016/j.cmet.2011.10.002. [139] S. Timmers, M. de Ligt, E. Phielix, T. van de Weijer, J. Hansen, E. Moonen-Kornips, G. Schaart, I. Kunz, M.K.C. Hesselink, V.B. Schrauwen-Hinderling, P. Schrauwen,

Resveratrol as Add-on Therapy in Subjects With Well-Controlled Type 2 Diabetes: A Randomized Controlled Trial, Diabetes Care. 39 (2016) 2211-2217. doi:10.2337/dc16-0499. [140] M. Kars, L. Yang, M.F. Gregor, B.S. Mohammed, T.A. Pietka, B.N. Finck, B.W. Patterson, J.D. Horton, B. Mittendorfer, G.S. Hotamisligil, S. Klein, Tauroursodeoxycholic Acid may improve liver and muscle but not adipose tissue insulin sensitivity in obese men and women, Diabetes. 59 (2010) 1899-1905. doi:10.2337/db10-0308.

[141] C. Hetz, E. Chevet, H.P. Harding, Targeting the unfolded protein response in disease, Nat. Rev. Drug Discov. 12 (2013) 703-719. doi:10.1038/nrd3976.

[142] L.V. Yuzefovych, S.P. LeDoux, G.L. Wilson, L.I. Rachek, Mitochondrial DNA damage via augmented oxidative stress regulates endoplasmic reticulum stress and autophagy: crosstalk, links and signaling, PloS One. 8 (2013) e83349. doi:10.1371/journal.pone.0083349. [143] L.V. Yuzefovych, V.A. Solodushko, G.L. Wilson, L.I. Rachek, Protection from palmitate-induced mitochondrial DNA damage prevents from mitochondrial oxidative stress, mitochondrial dysfunction, apoptosis, and impaired insulin signaling in rat L6 skeletal muscle cells, Endocrinology. 153 (2012) 92-100. doi:10.1210/en.2011-1442.

[144] K. Vannuvel, P. Renard, M. Raes, T. Arnould, Functional and morphological impact of ER stress on mitochondria, J. Cell. Physiol. 228 (2013) 1802-1818. doi:10.1002/jcp.24360.

[145] C. Giorgi, S. Missiroli, S. Patergnani, J. Duszynski, M.R. Wieckowski, P. Pinton, Mitochondria-associated membranes: composition, molecular mechanisms, and physiopathological implications, Antioxid. Redox Signal. 22 (2015) 995-1019. doi:10.1089/ars.2014.6223.

[146] C. López-Crisosto, R. Bravo-Sagua, M. Rodriguez-Peña, C. Mera, P.F. Castro, A.F.G. Quest, B.A. Rothermel, M. Cifuentes, S. Lavandero, ER-to-mitochondria miscommunication and metabolic diseases, Biochim. Biophys. Acta. 1852 (2015) 2096-2105.

doi:10.1016/j.bbadis.2015.07.011.

[147] P. Theurey, J. Rieusset, Mitochondria-Associated Membranes Response to Nutrient Availability and Role in Metabolic Diseases, Trends Endocrinol. Metab. TEM. 28 (2017) 3245. doi:10.1016/j.tem.2016.09.002.

[148] P. Theurey, E. Tubbs, G. Vial, J. Jacquemetton, N. Bendridi, M.-A. Chauvin, M.R. Alam, M. Le Romancer, H. Vidal, J. Rieusset, Mitochondria-associated endoplasmic reticulum membranes allow adaptation of mitochondrial metabolism to glucose availability in the liver, J. Mol. Cell Biol. 8 (2016) 129-143. doi:10.1093/jmcb/mjw004.

[149] J. Rieusset, J. Fauconnier, M. Paillard, E. Belaidi, E. Tubbs, M.-A. Chauvin, A.

Durand, A. Bravard, G. Teixeira, B. Bartosch, M. Michelet, P. Theurey, G. Vial, M. Demion, E. Blond, F. Zoulim, L. Gomez, H. Vidal, A. Lacampagne, M. Ovize, Disruption of calcium transfer from ER to mitochondria links alterations of mitochondria-associated ER membrane integrity to hepatic insulin resistance, Diabetologia. 59 (2016) 614-623. doi:10.1007/s00125015-3829-8. 
[150] E. Tubbs, P. Theurey, G. Vial, N. Bendridi, A. Bravard, M.-A. Chauvin, J. Ji-Cao, F. Zoulim, B. Bartosch, M. Ovize, H. Vidal, J. Rieusset, Mitochondria-associated endoplasmic reticulum membrane (MAM) integrity is required for insulin signaling and is implicated in hepatic insulin resistance, Diabetes. 63 (2014) 3279-3294. doi:10.2337/db13-1751. [151] A.P. Arruda, B.M. Pers, G. Parlakgül, E. Güney, K. Inouye, G.S. Hotamisligil, Chronic enrichment of hepatic endoplasmic reticulum-mitochondria contact leads to mitochondrial dysfunction in obesity, Nat. Med. 20 (2014) 1427-1435. doi:10.1038/nm.3735. [152] J.P. Muñoz, S. Ivanova, J. Sánchez-Wandelmer, P. Martínez-Cristóbal, E. Noguera, A. Sancho, A. Díaz-Ramos, M.I. Hernández-Alvarez, D. Sebastián, C. Mauvezin, M. Palacín, A. Zorzano, Mfn2 modulates the UPR and mitochondrial function via repression of PERK, EMBO J. 32 (2013) 2348-2361. doi:10.1038/emboj.2013.168.

[153] A.R. Konopka, A. Asante, I.R. Lanza, M.M. Robinson, M.L. Johnson, C. Dalla Man, C. Cobelli, M.H. Amols, B.A. Irving, K.S. Nair, Defects in mitochondrial efficiency and $\mathrm{H} 2 \mathrm{O} 2$ emissions in obese women are restored to a lean phenotype with aerobic exercise training, Diabetes. 64 (2015) 2104-2115. doi:10.2337/db14-1701.

[154] M.E. Osler, T. Fritz, K. Caidahl, A. Krook, J.R. Zierath, H. Wallberg-Henriksson, Changes in gene expression in responders and nonresponders to a low-intensity walking intervention, Diabetes Care. 38 (2015) 1154-1160. doi:10.2337/dc14-2606.

[155] L.M. Sparks, N.M. Johannsen, T.S. Church, C.P. Earnest, E. Moonen-Kornips, C. Moro, M.K.C. Hesselink, S.R. Smith, P. Schrauwen, Nine months of combined training improves ex vivo skeletal muscle metabolism in individuals with type 2 diabetes, J. Clin. Endocrinol. Metab. 98 (2013) 1694-1702. doi:10.1210/jc.2012-3874.

[156] M. Hey-Mogensen, K. Højlund, B.F. Vind, L. Wang, F. Dela, H. Beck-Nielsen, M. Fernström, K. Sahlin, Effect of physical training on mitochondrial respiration and reactive oxygen species release in skeletal muscle in patients with obesity and type 2 diabetes, Diabetologia. 53 (2010) 1976-1985. doi:10.1007/s00125-010-1813-x.

[157] R.C.R. Meex, V.B. Schrauwen-Hinderling, E. Moonen-Kornips, G. Schaart, M. Mensink, E. Phielix, T. van de Weijer, J.-P. Sels, P. Schrauwen, M.K.C. Hesselink, Restoration of muscle mitochondrial function and metabolic flexibility in type 2 diabetes by exercise training is paralleled by increased myocellular fat storage and improved insulin sensitivity, Diabetes. 59 (2010) 572-579. doi:10.2337/db09-1322.

[158] I. Pagel-Langenickel, D.R. Schwartz, R.A. Arena, D.C. Minerbi, D.T. Johnson, M.A. Waclawiw, R.O. Cannon, R.S. Balaban, D.J. Tripodi, M.N. Sack, A discordance in rosiglitazone mediated insulin sensitization and skeletal muscle mitochondrial content/activity in Type 2 diabetes mellitus, Am. J. Physiol. Heart Circ. Physiol. 293 (2007) H2659-2666. doi:10.1152/ajpheart.00782.2007. 